\title{
1 CROP YIELD, WEED INFESTATION AND SOIL FERTILITY RESPONSES TO \\ 2 CONTRASTED PLOUGHING INTENSITY AND MANURE ADDITIONS IN A \\ 3 MEDITERRANEAN ORGANIC CROP ROTATION
}

4

5

6 Paola Baldivieso-Freitas ${ }^{\text {a, b }}$, José M. Blanco-Moreno, ${ }^{\text {a, }}$, Laura Armengot ${ }^{\mathrm{a}, \mathrm{b}, \mathrm{c}}$, Lourdes

7 Chamorro ${ }^{\mathrm{a}, \mathrm{b}}$, Joan Romanyà ${ }^{\mathrm{d}, \mathrm{e}}$, Francisco Xavier Sans ${ }^{\mathrm{a}, \mathrm{b}}$

8

$9{ }^{\mathrm{a}}$ Department of Evolutionary Biology, Ecology and Environmental Sciences, University of 10 Barcelona, Av. Diagonal 643, 08028, Barcelona, Spain

$11{ }^{\mathrm{b}}$ Biodiversity Research Institute (IRBio)

$12{ }^{\mathrm{c}}$ Research Institute of Organic Agriculture (FiBL), 5070 Frick, Switzerland

$13{ }^{\mathrm{d}}$ Department of Natural Products, Plant Biology and Soil Science, University of Barcelona, Av.

14 Joan XXIII s/ n, 08028, Barcelona, Spain.

$15{ }^{\mathrm{e}}$ Research Institute of Nutrition and Food Safety (INSA), Av. Prat de la Riba, 171, 08921,

16 Barcelona, Spain 


\section{$17 \quad \underline{\text { Abstract }}$}

18 Conservation agriculture and organic farming are two alternative strategies that aim to improve

19 soil quality and fertility in arable cropping systems through reducing tillage intensity,

20 maintaining soil cover and increasing nutrient recycling, using farmyard and green manures.

21 However, these practices can increase weed infestation or decrease nutrient availability. The

22 objectives of this study were to evaluate the effects of tillage type (mouldboard vs. chisel

23 ploughing), fertilization and green manure on soil parameters (SOC, N, bulk density, carbon

24 stocks, and soil microbial biomass $\mathrm{C}_{\text {mic }}$ and $\mathrm{N}_{\text {mic }}$ ), weed abundance and crop yields in a four-

25 year rotation of spelt, chickpea, winter wheat and lentil in the Mediterranean region (Catalonia,

26 Spain). Tillage and green manure did not affect crop yields or weed biomass, although during

27 the last year of the experiment, plots with mouldboard ploughing had less weed biomass and

28 higher lentil biomass. Fertilization was the most important factor, increasing the cereal yields,

29 SOC, $\mathrm{N}$ and soil microbial biomass $\left(\mathrm{C}_{\mathrm{mic}}\right.$ and $\left.\mathrm{N}_{\text {mic }}\right)$ content of the soil. However, fertilization did

30 not favour chickpea and lentil crops because weed competition limited legume crop growth.

31 Overall, there was a loss of SOC and a reduction of carbon stocks over the four years of the trial

32 in the soil because of the deep soil tillage $(25 \mathrm{~cm})$ and low crop productivity irrespective of

33 tillage type. In contrast, $\mathrm{N}$ content increased in all of the plots and was enhanced by fertilization.

34 The use of chisel plough stratified the distribution of SOC and $\mathrm{N}$ in the surface layers $(0-10$

$35 \mathrm{~cm})$. Both $\mathrm{C}_{\text {mic }}$ and $\mathrm{C}_{\text {mic }} / \mathrm{SOC}$ ratio increased in fertilized treatments, suggesting an increased

36 lability of SOC. The application of more stabilized organic matter may be a better practice to

37 build up soil organic matter and to maintain crop yields in organic farming systems.

39 Keywords: chisel plough; carbon stock; amendments; microbial biomass; cover crop 


\section{INTRODUCTION}

42 Soils play a key role in agricultural systems because they represent the basis of food production

43 (Fließbach et al., 2007). However, most arable soils are prone to degradation, mainly caused by

44 intensive soil use (Gadermaier et al., 2012). Crop rotation, cover crops and reduced or no tillage

45 practices aim to improve soil quality in arable cropping systems. Farmyard manure and green

46 manure (organic fertilizers) can also contribute to soil fertility and quality. While most of these

47 practices are used in organic farming cropping systems, the adoption of reduced tillage practices

48 is not widespread in such systems (Gadermaier et al., 2012). The increase of weed infestation

49 and the limited availability of $\mathrm{N}$ mainly at the beginning of the growing season are probably the

50 main problems that reduced tillage pose to organic farmers (Gadermaier et al., 2012; Peigné et

51 al., 2007; Sans et al., 2011). On the other hand, reduced tillage is highly suited to conserve soil

52 fertility and prevent erosion (Berner et al., 2008; Gadermaier et al., 2012) by enhancing soil

53 organic carbon (SOC) content, microbial activity and soil structure (Mäder and Berner, 2012;

54 Peigné et al., 2013).

55 Cover crops can also contribute to the accumulation of organic matter in the upper soil layer and

56 they can reduce weed infestation (Hobbs et al., 2008; Masilionyte et al., 2017). However, the

57 use of cover crops must consider the possible consequences of competition for nutrients and

58 water with cash crops (Plaza-Bonilla et al., 2017).

59 Crop production in organic farms is often limited by the lack of nitrogen. In such farms nitrogen

60 inputs are needed to restore the amount of $\mathrm{N}$ depleted by crops (Fließbach et al., 2007). The use

61 of organic fertilizers, in one hand, is an effective way to increase soil organic matter content

62 (Alvarez, 2005) and N availability (Krauss et al., 2010; Lal, 2009; Maltas et al., 2013). On the

63 other hand, suitable crop rotations containing legumes are fundamental to produce surpluses in

64 N budgets (Gadermaier et al., 2012). However, the residue from a cover crop rich in legume

65 species is often mineralised very fast, and nutrients can be released before the demands of the 
subsequent cash crop (Pang and Letey, 2000) and thus be lost or used by weeds. Therefore, the use of cover crops for supplying $\mathrm{N}$ to crops must be adapted to the reduced tillage systems (Peigné et al., 2007). In consequence, it is considered of great interest to gain knowledge on the $\mathrm{N}$ dynamics after the introduction of green manures and reduced tillage practices in organic arable cropping systems.

Links between $\mathrm{C}$ and $\mathrm{N}$ cycling are important to understand $\mathrm{N}$ supply in arable systems. The application of organic manures, and reducing tillage intensity can increase the SOC in topsoil, improve soil physical and biological properties and lead to reduced carbon losses or even to increased soil carbon storage in the soil (Cooper et al., 2016; Gattinger et al., 2012). In addition, soil microbiological activity is of primary importance in organic farming because $\mathrm{N}$ supply is mainly dependent on the degradation of soil organic matter by soil micro-organisms (Vian et al., 2009). In this case, and because of their high sensitivity, $\mathrm{C}$ and $\mathrm{N}$ in soil microbial biomass can be used as indicators of changes in soil owing to management in the short term (Fließbach et al., 2007).

Few experiments integrate reduced tillage into organic farming systems, and most of them are performed in temperate climates (Berner et al., 2008; Krauss et al., 2010; Peigné et al., 2007; Pekrun et al., 2003). So far, in Mediterranean climates reduced tillage practices have been

83 studied only in conventional systems (Kassam et al., 2012; López-Garrido et al., 2014; Ward et 84 al., 2012), and thus there is a lack of long term reduced tillage studies in organic systems. The 85 low organic matter content with poor soil structure of the Mediterranean arable soils and the climatic constraints that limit plant growth during summer may constrain the chances to improve soil quality by means of reduced tillage and green manures (Kassam et al., 2012; Romanyà and Rovira, 2011; Hernanz et al, 2009).

Our aims were to study the effects of reduced tillage, farmyard manure and green manure (cover crop) on crop yields, weed abundance and soil organic $\mathrm{C}$ stocks and $\mathrm{N}$ availability. To address 
91 these aims we set in 2011 a mid-term experiment that was monitored during a four-year rotation

92 of spelt (Triticum spelta L., 2011-12), chickpea (Cicer arietinum L., spring 2013), winter wheat

93 (Triticum aestivum L., 2013-14) and lentil (Lens culinaris Medik., spring 2015).

94 We hypothesized that a) the lower disturbance of the soil profile by reduced tillage plus the

95 addition of farmyard and green manures contribute to an increase, or at least maintain SOC and

$96 \mathrm{~N}$ stocks. These changes, combined with the increased stability of the soil system, b) will

97 increase microbial biomass and $\mathrm{N}$ availability; and c) will allow a sustainable crop performance

98 in reduced tillage organic crops.

99

100 2. MATERIALS AND METHODS

101

2.1. Site conditions

102 In November of 2011, a midterm field experiment was initiated in Gallecs (41 ${ }^{\circ} 33^{\prime} 31.9^{\prime \prime} \mathrm{N}$

$\left.103 \quad 2^{\circ} 11^{\prime} 59.5 " \mathrm{E}\right)$, a peri-urban agricultural area of 753 ha situated $15 \mathrm{~km}$ north of Barcelona

104 (Catalonia, Spain). Gallecs has a Mediterranean climate; the mean annual temperature and

105 precipitation are $14.9^{\circ} \mathrm{C}$ and $647 \mathrm{~mm}$, respectively. At the beginning of the experiment, the soil

106 properties of the field were evaluated. On average, the mineral fraction consisted of $43.3 \pm$

$1076.9 \%$ sand, $26.9 \pm 4.7 \%$ loam and $29.7 \pm 3.7 \%$ clay; the texture was classified as loamy-clay

108 (Soil Survey Staff, 1998); the soil type was Haplic Luvisol (IUSS Working Group WRB, 2015);

109 the average soil organic matter was $1.5 \pm 0.1 \%$ (Walkley-Black); and the $\mathrm{pH}\left(\mathrm{H}_{2} \mathrm{O}\right)$ was $8.1 \pm$

$110 \quad 0.1$.

$111 \quad$ 2.2. Field experiment

112 The trial consisted of a four-year crop rotation in a strip-split-block design of three factors (with

113 two levels each): tillage system (mouldboard ploughing (P) vs. chisel (C)), fertilization

114 (composted farmyard manure (+F) vs. no fertilizer $(-\mathrm{F})$ ) and green manure (with green manure 
$115(+\mathrm{G})$ vs. no green manure $(-\mathrm{G}))$. The factors were arranged with tillage treatments laid out in

116 strips; fertilization was applied in perpendicular strips across the experiment, and the tillage

117 strips were split into subplots for the green manure treatment. In total, 32 plots measuring $13 \mathrm{~m}$

$118 \times 12 \mathrm{~m}$ were established, comprising four replicates of each treatment (Figure 1). The field had

119 been under organic management for five years prior to the trial establishment, with a typical

120 dryland Mediterranean crop rotation that alternated winter cereals and legumes in spring for

121 human consumption. The crop rotation of this trial consisted of spelt (2011-2012), chickpea

122 (2013), winter wheat (2013-2014) and lentil (2015) (Figure 2).

123 Two tillage systems were used: a mouldboard plough (P) (soil inversion at $25 \mathrm{~cm}$ depth) plus a

124 rotary harrow (5 $\mathrm{cm}$ depth), and a chisel plough (C) (no soil inversion at $25 \mathrm{~cm}$ depth) plus a

125 rotary harrow (same as for the mouldboard plough). The fertilization treatment $(+\mathrm{F})$ consisted of

126 partially composted farmyard manure, composed of cattle manure and plant residues, obtained

127 without managing and controlling the process, by gradually accumulating the material that was

128 seasonally available, according to the normal practice used in the area. In consequence, the

129 composted manure had a variable composition. The manure was applied every year before

130 sowing the main crop. The total amount of manure applied each year differed in relation to the

131 nutrient availability in the fertilizer and the nutritional demands of each crop (Table 1). The

132 organic fertilizers were mixed in the soil by means of a chisel or mouldboard plough in

133 accordance with the tillage treatment. In September 2012 and 2014, cover crops $(+\mathrm{G})$ were

134 sown in the corresponding 16 plots, consisting of a mixture of oat (Avena sativa L.), white

135 mustard (Sinapis alba L.), bitter vetch (Vicia ervilia (L.) Willd.) and common vetch (Vicia

136 sativa L.) (Table 1). At the end of March of the following year, cover crops (as well as the

137 weeds developing in $-\mathrm{G}$ treatment) were incorporated into the soil as green manure by disc

138 harrowing.

139 Weeds were not controlled during the first year of the crop rotation due to an extremely

140 prolonged rainy period that prevented the mechanical post-emergence weeding. In the second 
141 year of the rotation, weeds were controlled with an inter-row cultivator adapted to pass between

142 the seeding rows of chickpea. The third year of the rotation, weeds were controlled with a flex-

143 tine harrow during the wheat crop season. Finally, the last year of the rotation, lentil was

144 established poorly because of drought and was outcompeted by weeds despite the manual

145 removal of lamb's quarters individuals (Chenopodium album L.), which was the most important

146 weed during the lentils' growth (Table 1).

\subsection{Weed and crop assessment}

148 Crop density was evaluated every year once the crop plants were well-established. The

149 individuals were counted in a sample $0.5 \mathrm{~m}$ long, comprising two crop lines in four replicates in 150 each plot.

151 Before crop harvest, four permanent square frames of $1 \mathrm{~m}^{2}$ were randomly established, one in

152 each quarter of the plot, to assess weed and crop aboveground biomass. The total aboveground 153 biomass of weeds and crop was harvested in each frame and oven-dried at $60{ }^{\circ} \mathrm{C}$ for $48 \mathrm{~h}$. The 154 aboveground biomass of green manure and weeds was also evaluated during the green manure 155 period. Grain crop yield was assessed in the inner $9 \mathrm{~m} \times 8 \mathrm{~m}$ of each plot by a plot combine 156 each year (except for lentils). The straw of the crops was not removed from the field and was 157 incorporated with the stubble into the soil by disc harrowing at $10 \mathrm{~cm}$ deep. The spelt straw was

158 chopped by a hammer straw chopper before being incorporated

\subsection{Soil sampling and analyses of SOC, N, bulk density and carbon stocks}

160 In November 2011 and 2015, the soil was studied at four depths: from 0 to $10 \mathrm{~cm}$, from 10 to $16120 \mathrm{~cm}$, from 20 to $30 \mathrm{~cm}$ and from 30 to $40 \mathrm{~cm}$. The first two depths were sampled in all of the 162 plots, whereas the two deepest soil layers were sampled only in plots with farmyard manure and 163 green manure with mouldboard ploughing and with chisel ploughing $(\mathrm{P}+\mathrm{F}+\mathrm{GM}$ and $\mathrm{C}+\mathrm{F}+$

164 GM). To study soil bulk density, 3 soil cores of $6.2 \mathrm{~cm}$ diameter and $10 \mathrm{~cm}$ deep were extracted 
165 in each soil layer at each plot. Soil samples were oven-dried at $90-100{ }^{\circ} \mathrm{C}$ for $48 \mathrm{~h}$. Soil bulk

166 density was calculated according to the following formula: Bulk density $\left(\mathrm{g} \mathrm{cm}^{-3}\right)=$ dry soil 167 weight $(\mathrm{g}) /$ core volume $\left(\mathrm{cm}^{3}\right)$.

168 To study total soil organic carbon (SOC) and total nitrogen content (N), 20 soil cores of $2.5 \mathrm{~cm}$

169 of diameter were systematically extracted every 2 meters of distance in each plot. Each set of 20

170 cores extracted at each plot and depth constituted a sample. Soil samples were kept in plastic

171 bags, properly labelled, in a fridge at $4{ }^{\circ} \mathrm{C}$ until analysis. Samples were air dried and sieved on a

$1722 \mathrm{~mm}$ mesh. A minimum amount of $50 \mathrm{~g}$ dried soil was prepared for SOC and $\mathrm{N}$ analysis, and

173 the rest was separated for the soil microbial analyses (see below section 2.5). Total carbon and

174 total nitrogen were analysed through dry combustion with a LECO $\odot$ Truspec CHNS analyser

175 (Bremner, 1996). The Walkley-Black procedure/ISO 14235 was finally chosen to indirectly

176 estimate the soil organic carbon (SOC) due to the high proportion of carbonates.

177 Based on the soil bulk density and SOC, carbon stocks were calculated according to the

178 following formula (Lee et al., 2009): Soil carbon stock $\left(\mathrm{g} \mathrm{m}^{-2}\right)=$ soil carbon content

$179\left(\mathrm{mg} \mathrm{g}^{-1}\right) \times$ depth of soil layer $(\mathrm{m}) \times$ area $\left(\mathrm{m}^{2}\right) \times$ bulk density $\left(\mathrm{g} \mathrm{cm}^{-3}\right) \times 10^{6}$.

$180 \quad 2.5$. Soil microbial biomass analyses

181 All of the soil microbial analyses were carried out on moist soil samples adjusted to a water

182 content corresponding to $40-50 \%$ of maximum water retention capacity. The soil microbial

183 biomass $\left(\mathrm{C}_{\text {mic }}\right.$ and $\left.\mathrm{N}_{\text {mic }}\right)$ was estimated using chloroform fumigation extraction (CFE) following

184 Vance et al. (1987). CFE was done in triplicate on $20 \mathrm{~g}$ (dry matter) subsamples that were

185 extracted with $80 \mathrm{ml}$ of a $0.5 \mathrm{M} \mathrm{K}_{2} \mathrm{SO}_{4}$ solution. Total organic carbon (SOC) in soil extracts was

186 determined by infrared spectrometry after combustion at $850^{\circ} \mathrm{C}$. Total nitrogen $(\mathrm{N})$ was

187 measured subsequently in the same sample by chemoluminescence. The soil microbial biomass

188 was then calculated according to the formula: $\mathrm{C}_{\text {mic }}\left(\mu \mathrm{g} \mathrm{g}{ }^{-1}\right.$ oven dry soil $)=\mathrm{EC} / k_{E C}$, where $\mathrm{EC}=$

189 (SOC in fumigated samples - SOC in control samples) and $k_{E C}=0.45$ (Joergensen, 1996). $\mathrm{N}_{\text {mic }}$ 
$190\left(\mu \mathrm{g} \mathrm{g}^{-1}\right.$ oven dry soil $)=\mathrm{EN} / k_{\mathrm{EN}}$, where $\mathrm{EN}=(\mathrm{N}$ extracted from fumigated samples $-\mathrm{N}$

191 extracted from control samples) and $k_{\mathrm{EN}}=0.40$ (Joergensen and Mueller, 1996).

\subsection{Statistical analyses}

193 The individual and combined effects of the type of tillage (P vs. C), fertilization (+F vs. $-\mathrm{F}$ ) and

194 green manure (+G vs. $-\mathrm{G}$ ) on crop yields (spelt, chickpea, winter wheat), lentil aboveground

195 biomass and weed aboveground biomass were evaluated using linear mixed effects models. For

196 spelt crop, the factor of green manure was not analysed because the green manure crop was

197 implemented after it. The weed biomass was introduced in the models as a covariate to evaluate

198 the effect of weeds on grain yields (or crop biomass, when yield was not available). Tillage,

199 fertilization and green manure were used as fixed factors, and the block was introduced as a

200 random factor. The normality of residuals was verified using the Shapiro-Wilk test, and

201 homoscedasticity was assessed using Bartlett's test. To meet the normality and

202 homoscedasticity requirements, we used logarithmic or square root transformation on the data

203 when necessary. The same statistical procedure was followed to analyse the effects of tillage,

204 fertilization, green manure and depth of the soil layers and the interaction between the factors on

205 the following soil parameters: SOC, N, soil bulk density, carbon stocks, and soil microbial

206 biomass $\left(\mathrm{C}_{\mathrm{mic}}\right.$ and $\left.\mathrm{N}_{\mathrm{mic}}\right)$. The changes in soil quality indicators over the 4-year rotation were also

207 studied, comparing soil samplings carried out twice during the experiment $\left(\Delta=\mathrm{t}_{\mathrm{f}}-\mathrm{t}_{\mathrm{i}}\right)$. The first

208 analysis was performed at the beginning of the trial, representing the initial status of the soil $\left(\mathrm{t}_{\mathrm{i}}\right)$,

209 and the second analysis was performed at the end of the experiment $\left(\mathrm{t}_{\mathrm{f}}\right)$. All the analyses were

210 performed in R version 3.2.2 (R Development Core Team, 2015) using the package lme4 (Bates

211 et al., 2015) for linear mixed effects model fitting. 


\subsection{Crop yields and weed biomass}

215 No differences in the density (individuals $/ \mathrm{m}^{2}$ ) of the established crops were found between

216 treatments in the first two years (spelt and chickpea), although the establishment of winter

217 wheat and lentil differed according to the type of tillage and the presence or not of green manure

218 the previous year (wheat) or months (lentil). Wheat establishment was significantly higher in

219 plots with mouldboard ploughing and no green manure compared to chisel (T (P vs. C) $\times \mathrm{G}(+\mathrm{G}$

220 vs. $-\mathrm{G}): \mathrm{p}=0.009)$. More plants of lentil emerged in plots with no green manure in general, and

221 in plots with green manure, crop emergence was significantly higher in plots with mouldboard

222 ploughing $((\mathrm{T}(\mathrm{P}$ vs. $\mathrm{C}) \times \mathrm{G}(+\mathrm{G}$ vs. $-\mathrm{G}): \mathrm{p}=0.04)$.

223 The winter wheat crop had the highest yields $\left(3200 \pm 280.08 \mathrm{~kg} \mathrm{ha}^{-1}\right)$, followed by spelt (2328

$\left.224 \pm 100.51 \mathrm{~kg} \mathrm{ha}^{-1}\right)$ and chickpea $\left(384 \pm 65.38 \mathrm{~kg} \mathrm{ha}^{-1}\right)$. Lentil did not produce grain because

225 extended drought dramatically affected both flowering and fruiting. Cereal yields were

226 significantly higher in plots with fertilization; both the spelt and winter wheat yields were

227 higher in plots with farmyard manure (Table 2 and Figure 3). Legumes did not follow the same

228 trend; the chickpea yield and lentil biomass did not vary in relation to fertilization. Regarding

229 the effects of the type of tillage and the incorporation of cover crops as green manure, crop

230 yields did not vary significantly, with the exception of lentil biomass. The lentil biomass was

231 significantly higher in plots that underwent mouldboard ploughing (Table 2 and Figure 3).

232 The effect of tillage on aboveground weed biomass varied over time. Although no significant

233 differences were found in the first two crops in the rotation, the aboveground weed biomass was

234 significantly lower in plots tilled with mouldboard ploughing than in plots tilled with chisel

235 ploughing during wheat and lentil crop. The incorporation of the cover crop as green manure did

236 not affect weed biomass during subsequent crops of chickpea (in the same year) and winter

237 wheat (in the following year). However, in the fourth year (during the lentil crop), weed 
238 biomass was significantly higher in plots in which cover crops had been incorporated into the

239 soil prior to lentil seeding. No statistically significant interaction between factors were found,

240 with the exception of a significant lower weed biomass in plots with fertilization and

241 mouldboard ploughing in the spelt crop (Table 2).

242 The results showed that the weed biomass did not affect spelt and winter wheat grain yield

243 (slope for the effect of weed biomass on spelt yield: $1.60 \pm 4.17, p=0.7$ and slope for the

244 effect of weed biomass on winter wheat yield: $-6.54 \pm 26.99, p=0.8)$. In contrast, chickpea

245 yield and lentil biomass correlated negatively with weed biomass (slope for the effect of weed

246 biomass on chickpea yield: $\mathrm{p}<0.001$ and slope for the effect of weed biomass on lentil

247 biomass: $\mathrm{p}=0.003)$.

248 Green manure biomass did not differ between treatments in 2013 or 2015 . The analysis of the

249 effect of the green manure on weed abundance and on the crop yield of the subsequent crop

250 demonstrates that cover crop was effective in controlling weeds during its growing season but

251 not the following year. The effect of green manure on the control of weed biomass was

252 statistically significant (+G vs. -G: $p<0.001$ in 2013 and 2015). 
254 Overall, SOC decreased significantly ( $\mathrm{t}_{\mathrm{f}}$ vs. $\left.\mathrm{t}_{\mathrm{i}}: \mathrm{p}<0.001\right)$ in all of the treatments over the 4-year rotation of the experiment, with the exception of the soil layer between 0 to $10 \mathrm{~cm}$ deep in plots with chisel plough and fertilization. In contrast, $\mathrm{N}$ content increased across all the treatments $\left(\mathrm{t}_{\mathrm{f}}\right.$ vs. $\left.\mathrm{t}_{\mathrm{i}}: \mathrm{p}<0.001\right)$ (Table 3 and Figure 4). The highest SOC losses occurred at superficial soil layers $(0$ to $10 \mathrm{~cm})$ of plots without fertilization. SOC decreases were significantly higher at deeper soil layers (10 to $20 \mathrm{~cm}$ ) of plots with chisel plough (C) than of plots with soil layers inversion using mouldboard ploughing (P) (Table 4). Although no significant interaction was found between the type of tillage and fertilization, our results showed that SOC content at 0 to $10 \mathrm{~cm}$ was maintained over the 4-year rotation in plots with chisel and fertilization (Table 3 and Figure 4).

264 Regarding the changes in $\mathrm{N}$ content, the highest increases occurred in plots with fertilization 265 (Table 3). The type of tillage also affected $\Delta \mathrm{N}$; plots with chisel ploughing had higher increase 266 than plots with mouldboard ploughing (Table 4 and Figure 4). However, this significant 267 increase in $\mathrm{N}_{\mathrm{t}}$ content occurred at the top soil layer of plots with chisel and fertilization, as 268 indicated by the significant interaction between fertilization, tillage and soil layer (Table 4).

269 Green manure did not show any effect. No significant differences were found in $\triangle \mathrm{SOC}$ and $270 \Delta \mathrm{N}_{\text {tot }}$ over the 4-year rotation of the trial according to the presence of green manure.

271 Overall, the C:N ratio of the soil decreased by $32 \%$ after the four years $\left(\mathrm{t}_{\mathrm{f}} \mathrm{vs} . \mathrm{t}_{\mathrm{i}}: \mathrm{p}<0.001\right)$, and 272 there was a significant interaction between tillage and fertilization, indicating a higher C:N ratio 273 in plots with fertilization and reduced tillage compared to plots with mouldboard ploughing, 274 irrespective of the soil layer (Table 4). inputs 
277 After four years of the experiment, soil bulk density did not vary significantly in relation to the

278 different experimental factors. Deeper soil layers had a higher bulk density than surface layers,

279 but this pattern was not associated with the type of tillage or the organic fertilizer inputs, such as

280 composted farmyard manure and green manure (Table 5).

281 Carbon stocks, assessed from the SOC content and the soil bulk density of soil samples in

282 different soil layers, were significantly higher in plots fertilized with composted farmyard manure

283 and were higher at deeper soil layers from 10 to $20 \mathrm{~cm}$ (Table 5), although this is mainly

284 associated with higher bulk density. Furthermore, there was a significant interaction with the type

285 of tillage and green manure; higher carbon stocks were detected in plots with chisel and green

286 manure. The effect of the treatments at different soil layers showed some significant results as

287 well. Carbon stocks were higher at deeper soil layers in plots with fertilization, and the plots with

288 mouldboard ploughing presented lower carbon stocks at superficial soil layers (Table 5).

289 The diachronic analyses of carbon stocks over the 4-year rotation at four different soil layers (0 to

$29010 \mathrm{~cm}, 10$ to $20 \mathrm{~cm}, 20$ to $30 \mathrm{~cm}$ and 30 to $40 \mathrm{~cm})$ in relation to the tillage $(\mathrm{P}+\mathrm{F}+\mathrm{GM}$ and $\mathrm{C}+\mathrm{F}$

$291+$ GM) indicate that carbon stocks were significantly lower in deeper soil layers (soil layer 20 to

$29230 \mathrm{~cm}$ vs. superficial soil layers: $\mathrm{p}<0.001$; and 30 to $40 \mathrm{~cm}$ vs. superficial soil layers: $\mathrm{p}<0.001$ ).

293 Overall, carbon stocks decreased after four years, irrespective of the soil layer $(p=0.01)$, and the

294 negative effect of soil layer inversion using mouldboard ploughing was only statistically

295 significant in the two upper soil layers ( 0 to 10 and 10 to $20 \mathrm{~cm}, \mathrm{p}<0.001$ ).

296 3.4. Changes in soil microbial biomass

297 Soil microbial biomass (assessed as the $\mathrm{C}_{\text {mic }}$ and $\mathrm{N}_{\text {mic }}$ ) was significantly higher in plots with

298 farmyard manure (Table 6 and 7). Furthermore, soil microbial biomass was lower at deeper soil

299 layers, and the significant interaction with fertilization reflects differences in $\mathrm{C}_{\text {mic }}$ and $\mathrm{N}_{\text {mic }}$ in

300 fertilized and unfertilized plots (Table 7). Superficial soil layers showed greater differences

301 between fertilized and plots without fertilization in $\mathrm{C}_{\text {mic }}$ and $\mathrm{N}_{\text {mic, }}$, compared to soil layers at 10

302 to $20 \mathrm{~cm}$. Plots with mouldboard ploughing showed similar $\mathrm{C}_{\mathrm{mic}}$ at $0-10 \mathrm{~cm}$ depth and at 10 to 
304 biomass at superficial soil layers compared to the deeper soil layers (Table 6 and Figure 5). The

305 highest $\mathrm{C}_{\text {mic }}$ was observed in superficial layers $(0$ to $10 \mathrm{~cm})$ in plots with farmyard manure and

306 chisel ploughing (Figure 5). $\mathrm{N}_{\text {mic }}$ did not vary significantly between soil layers in interaction

307 with tillage, and $\mathrm{C}_{\text {mic }}$ and $\mathrm{N}_{\text {mic }}$ were not significantly affected by the presence or absence of

308 green manure (Table 6 and 7).

309 The comparison of $\mathrm{C}_{\text {mic }}$ and $\mathrm{N}_{\text {mic }}$ between superficial and deeper soil layers in relation to the

310 tillage (plots $\mathrm{P}+\mathrm{F}+\mathrm{GM}$ vs. plots $\mathrm{C}+\mathrm{F}+\mathrm{GM}$ ) indicate that both $\mathrm{C}_{\mathrm{mic}}$ and $\mathrm{N}_{\text {mic }}$ were decreased

311 in deeper soil layers (20 to $30 \mathrm{~cm} \mathrm{C}_{\text {mic }}$ : $\mathrm{p}<0.001, \mathrm{~N}_{\text {mic }}$ : $\mathrm{p}<0.001$ and 30 to $40 \mathrm{~cm} \mathrm{C}_{\text {mic }}$ : $\mathrm{p}<0.001$,

$312 \mathrm{~N}_{\text {mic }}: \mathrm{p}<0.001$ ), although no significant differences were found in relation to tillage (data not

313 shown).

314 The differences in $\mathrm{C}_{\text {mic }}$ and $\mathrm{N}_{\text {mic }}$ between the first and last year of the trial $\left(\Delta \mathrm{C}_{\text {mic }}\right.$ and $\left.\Delta \mathrm{N}_{\text {mic }}\right)$ did

315 not vary in relation to the individual factors (tillage, fertilization and green manure). $\mathrm{C}_{\text {mic }}$

316 increased overall after the four years of the trial $\left(t_{f}\right.$ vs. $\left.t_{i}: p<0.001\right)$. Significant interactions were

317 found between fertilization, tillage and soil depth, indicating higher increases of $\mathrm{C}_{\text {mic }}$ in plots

318 with chisel plough (T: P vs. C: $\mathrm{p}<0.001$ ) and fertilization (F: + vs. -: $\mathrm{p}<0.001$ ) at 0 to $10 \mathrm{~cm}$ and

319 decreases in the 10 to $20 \mathrm{~cm}$ layer (depth 10 to 20 vs. 0 to $10 \mathrm{~cm}: \mathrm{p}<0.001$ ). In contrast, plots

320 with mouldboard ploughing did not show significant changes in $\mathrm{C}_{\text {mic }}$ at different soil depths.

321 The $\mathrm{N}_{\text {mic }}$ decreased, in general, in all the plots after the four years of the trial $\left(\mathrm{t}_{\mathrm{f}} \mathrm{vs} . \mathrm{t}_{\mathrm{i}}: \mathrm{p}<0.001\right)$,

322 but the highest losses of $\mathrm{N}_{\text {mic }}$ were at superficial soil layers (depth 10 to $20 \mathrm{vs.} 0$ to $10 \mathrm{~cm}$ :

$323 \mathrm{p}<0.001)$. Additionally, there was a significant interaction between the year and the type of

324 tillage, indicating lower $\mathrm{N}_{\text {mic }}$ values in the last year in plots with chisel (T: $\mathrm{P}$ vs. $\mathrm{C}: \mathrm{p}=0.02$ );

325 this was associated with the superficial layers, although no significant interactions were found

326 (data not shown). 
327 The $\mathrm{C}_{\text {mic }} / \mathrm{SOC}$ ratio increased in all of the plots after the four years of the experiment $\left(\mathrm{t}_{\mathrm{f}} \mathrm{vs.} \mathrm{t}_{\mathrm{i}}\right.$ :

$328 \mathrm{p}<0.001)$. Furthermore, the $\mathrm{C}_{\mathrm{mic}} / \mathrm{SOC}$ after the four years of the experiment varied significantly 329 with soil depth, and this factor also interacted significantly with the fertilization and the type of 330 tillage (Table 7). We found the highest ratio at the superficial layers in plots with chisel plough 331 and no fertilization compared to plots with chisel plough and no fertilization at deeper soil 332 layers (Table 7 and Figure 5). 


\subsection{Crop yields and weed biomass}

336 Our study reveals that fertilization is the most important factor affecting crop yields, particularly

337 during the cereal cropping period. Organic systems rely upon the use of organic fertilizers and

338 amendments that typically release nutrients (especially $\mathrm{N}$ ) at a slower rate compared with

339 mineral fertilizers. Nitrogen inputs are critical to the productivity of these systems, and the

340 application of farmyard manure seems to be effective to maintain cereal yields (Fließbach et al.,

341 2007; Maltas et al., 2013). Conversely, the grain yield of chickpea and aboveground biomass of

342 lentil were not increased by fertilization. In general, legumes do not need supplemental N

343 fertilization (Clayton et al., 2003) because they can obtain a significant proportion of its $\mathrm{N}$ by

344 symbiotic nitrogen fixation (Walley et al., 2005).

345 The type of tillage had no significant effects on grain yields of cereals (spelt and winter wheat)

346 and chickpea. Other studies under Mediterranean conditions obtained similar results (López-

347 Garrido et al. 2014). However, many studies from temperate regions reveal lower crop yields in

348 systems with no soil layer inversion by chiselling (Cooper et al., 2016) because of a

349 combination of a shortage of nutrients and competition from weeds (Mäder and Berner, 2012;

350 Peigné et al., 2013). Indeed, the lower biomass of lentil in plots with reduced tillage can be

351 explained by the higher weed biomass under these conditions.

352 The positive effect of fertilization and mouldboard ploughing in controlling weeds in spelt and

353 winter wheat highlights the importance of both factors in enhancing the competitive ability of

354 crops. Weed abundance did not affect significantly spelt and winter wheat grain yield,

355 indicating that the crop was able to suppress the growth of weeds to a point where their effect

356 on crop growth was negligible. In contrast, the effect of weed biomass on chickpea yields and

357 lentil crop biomass was statistically significant, indicating a strong negative correlation between

358 weeds and legume crops. The growth of weeds was significantly enhanced by fertilization 
359 during legume crops and, consequently, they significantly reduced the growth of chickpea and

360 lentil. Some studies indicated that lentil is very vulnerable to weed competition because of its

361 short stature, slow establishment, and limited vegetative growth (Ahmadi et al., 2016). The high

362 amount of weed biomass in chickpea and lentil irrespective of the treatment can be related to the

363 inadequate post-emergence weed control. Our results indicated that mouldboard ploughing

364 increased weed control and consequently lentil crop biomass. Therefore, improving weed

365 management in legume crops is critical to their feasibility in organic farming because of the

366 high susceptibility of such crops to weed competition.

367 Although we expected a negative or neutral effect of green manures on weed abundance, green

368 manure increased weed abundance during the subsequent lentil crop. The extremely weak

369 growth of lentil as a result of drought may have reduced the competitive ability of the crop and

370 promoted weed growth. These results call for a careful evaluation of the insertion of cover crops

371 in Mediterranean crop rotations (Plaza-Bonilla et al. 2017).

4.2. Changes in SOC, carbon stocks and $\mathrm{N}$ change during the experiment?

373 The amount of SOC stored in the soil is determined by the balance production of organic matter

374 by plants and decomposition of organic matter by soil organisms. Each of these processes is

375 controlled by physical, chemical, and biological factors (Guo and Gifford, 2002). In organic

376 arable cropping systems, the intensity of soil disturbance, the farmyard manure and green

377 manure fertilization are overriding factors that determine the amounts of SOC and N and their

378 pattern of distribution in the soil profile (Gattinger et al., 2012). Some authors have indicated

379 that SOC is enhanced by reduced tillage practices after several years (Mäder and Berner, 2012;

380 Peigné et al., 2013). However, other studies were unable to demonstrate such a positive effect

381 (Berner et al., 2008). Our study shows losses of SOC irrespective of the ploughing intensity,

382 indicating that Mediterranean low input farming systems may reduce SOC content and

383 consequently soil carbon stocks. It is interesting to note that such losses were lower in plots with 
384 chisel than in plots with mouldboard ploughing. Similar to other studies, reduced tillage

385 stratified SOC and consequently soil carbon stocks and microbial biomass concentrated in the

386 upper layers especially in fertilized plots (Berner et al., 2008, Cooper et al., 2016, Gadermaier et

387 al., 2012). It is worthy to highlight that soil inversion by mouldboard ploughing reduces

388 carbon stocks in the topsoil mainly in unfertilized soils while it increases SOC at deeper layers.

389 As the SOC losses also occurred in reduced tillage treatments, they must relate to other aspects

390 of organic farming practices. Crop productivity is one of the main drivers of carbon stocks in

391 arable systems. Both carbon stocks and crop productivity may be enhanced by crop fertilization

392 practices (Johnston et al., 2009). The cereal grain yield even in our fertilized plots was less than

393 half that of conventional systems in the region (Ministerio de Agricultura y Pesca, Alimentación

394 y Medio Ambiente, 2009), indicating a low plant productivity in comparison to neighbouring

395 cereal monocultures. This may explain SOC losses throughout the soil profile. Moreover, low

396 productivity of legume crops as compared to cereals may further contribute to decrease soil

397 organic matter in such crop rotations. These SOC loses may be partly compensated by the

398 addition of farmyard manure. In these experimental systems, organic fertilization was crucial to

399 maintain SOC level and to enhance cereal crop productivity, but it reduced productivity in

400 legume crops. This suggests in one hand nutrient limitation for cereal productivity and on the

401 other hand a negative effect of organic fertilization in rotations including legumes. As the use of

402 fresh, unstabilized materials may induce the mineralization of native SOC stocks (Molina-

403 Herrera and Romanyà, 2015; Romanyà et al., 2012), the addition of more stabilized composted

404 organic materials may have contributed to building up SOC stocks.

405 There is a broad support in the literature for the positive effects of cover crops on SOC (Poeplau

406 and Don, 2015). However, our results suggest that the incorporation of crop residues with low

407 C:N ratio, such as those from legumes, into the soil can accelerate SOC decomposition,

408 although other studies show positive responses on SOC levels in response to legumes (Beedy et

409 al., 2010). The lack of response of green manure in our experiment may have been due to the 
410 general low plant productivity in the experimental area or lack of effect over short time-spans

411 (Biederbeck et al., 1998).

$412 \mathrm{~N}$ content was clearly enhanced after the 4-year rotation in all the plots. Our results show that $\mathrm{N}$

413 increase was significantly higher with the incorporation of farmyard manure, and the highest

414 increase occurred in plots with reduced tillage. Increased $\mathrm{N}$ levels after adding manures have

415 also been reported by other authors (Krauss et al., 2010; Maltas et al., 2013). In contrast, we did

416 not find any significant effect of the incorporation of green manure on the increase of the $\mathrm{N}$,

417 indicating that the effect of applying farmyard manure was more important. Slight increases of

$418 \mathrm{~N}$ amount in unfertilized plots can be attributed to $\mathrm{N}$ fixation or to atmospheric deposition (Pang

419 and Letey, 2000), which in the area may be as high a 15-22 $\mathrm{kg} \mathrm{ha}^{-1}$ year ${ }^{-1}$ (Vallejo et al., 2005).

420 In our experimental site in Gallecs this value can be especially high because of its proximity to

421 urban areas (highways, industry, etc.) (Ochoa-Hueso et al., 2011).

\subsection{Changes in soil microbial biomass and $\mathrm{N}$ availability}

424 Reduced tillage caused a stratification of soil microbial biomass in the soil profile, which

425 parallels total SOC content. In agreement with previous studies (Vian et al., 2009), our results

426 on microbial biomass $\left(\mathrm{C}_{\text {mic }}\right.$ and $\left.\mathrm{N}_{\text {mic }}\right)$ indicated that shifting from conventional to reduced tillage

427 modifies crop residue distribution in the soil profile and environmental conditions for soil

428 micro-organisms. Increased organic residues in top layers may go along with a decrease in the

429 turnover rate of the SOC that may increase $\mathrm{N}$ immobilization and produce $\mathrm{N}$ shortages for crops

430 (Pekrun et al., 2003; Vian et al., 2009).

431 In our experiment, the increase of $\mathrm{C}_{\text {mic }}$ after four years of trial can be mainly explained by the

432 addition of manures. The addition of labile sources of SOC promotes soil microbial activity and 433 consequently an increase of microbial biomass (Molina-Herrera and Romanyà, 2015; Fließbach 
434 and Mäder, 2000). Reduced tillage has also been found to increase microbial biomass in surface

435 soils, although its effects have been found to be much stronger when combined with

436 fertilization. These increases, however, have not been related to increases in $\mathrm{N}$ availability.

437 Indeed, some studies in temperate climates reported a decrease of $\mathrm{N}$ availability for the crop

438 under reduced tillage due to lower mineralization rates (Berner et al., 2008; Peigné et al., 2007).

439 The decrease of $\mathrm{N}_{\text {mic }}$ that ocurred in all treatments after four years of trial coincided with a $32 \%$

440 decrease in the $\mathrm{C}: \mathrm{N}$ ratio (see section 3.2). A low $\mathrm{C}: \mathrm{N}$ ratio indicates an increased degree of

441 humification (Bayer et al., 2002). Humified organic matter strongly holds $\mathrm{N}$ in highly

442 recalcitrant forms and is thus unavailable to soil microbiota. In our experiment, low $\mathrm{N}$

443 availability was indicated by the decreased $\mathrm{N}_{\text {mic }}$. $\mathrm{N}$ mobilization in such soils may involve

444 destabilization of soil organic matter and its subsequent mineralization (Clarholm et al., 2015).

445 This may coincide with increases in fungi and Gram (+) bacteria as has been reported by other

446 authors studying organically managed minimum tillage farming systems (Sun et al., 2016).

447 The $\mathrm{C}_{\text {mic }} / \mathrm{SOC}$ ratio can indicate the soil microbial efficiency of conversion of organic matter to

448 microbial biomass and the stabilization of SOC by the soil mineral fractions (Sparling, 1992). In

449 our mid-term trial, the loss of SOC in all the plots coincides with the increase of the $\mathrm{C}_{\text {mic }} / \mathrm{SOC}$

450 ratio, which indicates that the microorganisms are integrating a greater proportion of soil

451 organic matter. 


\section{CONCLUSIONS}

453 Farmyard manure is the main factor affecting crop yields and weed biomass, as well as soil

454 fertility and quality. Organic fertilization is crucial to sustain cereal yields, but can also exert a

455 negative effect on legume crops by increasing the competitive effects of weeds. Although

456 farmers are concerned that reduced tillage could reduce the already low crop yields under

457 organic farming by increasing weed pressure and delaying nutrient mineralization, we have

458 found that the concerns are unfounded. The tillage system does not have a consistent negative

459 effect on yields, and the increased weed control of mouldboard plough only occurs in the mid-

460 to long-term. The implementation of green manure in dryland areas requires a careful redesign

461 of the cropping system. Although applying green manure could alleviate some fertility and

462 weed control issues, we have not found positive effects on crop yields.

463 In the Mediterranean region of Spain, soils have low $\mathrm{N}$ availability and the organic fertilization

464 might not be enough to maintain SOC content. Future research should explore the effects of

465 applying more stabilized organic matter, which may be a better practice for the enhancement of

466 soil quality and the build-up of soil organic matter in the soil. 
468 The authors wish to acknowledge the efforts of all researchers who participated in this

469 experiment. We sincerely thank the people involved in field activities, particularly Alejandro

470 Pérez-Ferrer for technical assistance and Salvi Safont for his willingness and experience in

471 running the machinery needed to perform the field management.

472 Funding: We thank the economic support of the Ministry of Economy and Competitiveness

473 through the National Institute of Agrarian and Food Research and Technology (INIA), part of

474 the CORE Organic Plus funding bodies, which in turn are partners of FP7 ERA-Net and

475 financed by the European Commission through projects TILMAN-ORG and FERTILCROP,

476 which allowed this work to be carried out. This research has also been partially funded by the

477 Department of Agriculture, Livestock, Fisheries and Food of Catalonia (projects 2011 AGEC

478 001, 2012 AGEC 00027, 5305007 2015) and by a fellowship from the Spanish Ministry of

479 Education, Culture and Sports to the first author.

480 
482 Ahmadi, A.R., Shahbazi, S., Diyanat, M., 2016. Efficacy of five herbicides for weed control 483 in rain-fed lentil (Lens culinaris Medik.). Weed Technol. 30, 448-455.

484

486

487

Alvarez, R., 2005. A review of nitrogen fertilizer and conservation tillage effects on soil organic carbon storage. Soil Use Manag. 21, 38-52.

Bates, D., Mächler, M., Bolker, B., Walker, S., 2015. Fitting linear mixed-effects models using lme4. J. Stat. Softw. 67, 1-48.

Bayer, C., Mielniczuk, J., Martin-Neto, L., Ernani, P.R., 2002. Stocks and humification degree of organic matter fractions as affected by no-tillage on a subtropical soil. Plant Soil 238, $133-140$.

Beedy, T.L., Snapp, S.S., Akinnifesi, F.K., Sileshi, G.W., 2010. Impact of Gliricidia sepium intercropping on soil organic matter fractions in a maize-based cropping system. Agr. Ecosyst. Environ. 138, 139-146.

Berner, A., Hildermann, I., Fließbach, A., Pfiffner, L., Niggli, U., Mäder, P., 2008. Crop yield and soil fertility response to reduced tillage under organic management. Soil Tillage Res. 101, 89-96.

Biederbeck, V.O., Campbell, C.A., Rasiah, V., Zentner, R.P., Wen, G., 1998. Soil quality attributes as influenced by annual legumes used as green manure. Soil Biol. Biochem. 30, $1177-1185$.

Bremner, J.M., 1996. Nitrogen-total. Methods Soil Anal. Part 3 - Chemical Methods 1085-1121

Clarholm, M., Skyllberg, U., Rosling, A., 2015. Organic acid induced release of nutrients from metal-stabilized soil organic matter - The unbutton model. Soil Biol. Biochem, 84, 168- 
504

505

Clayton, G.W., Rice, W.A., Lupwayi, N.Z., Johnston, A.M., Lafond, G.P., Grant, C.A., Walley, F., 2004. Inoculant formulation and fertilizer nitrogen effects on field pea: Nodulation, $\mathrm{N}_{2}$ fixation, and nitrogen partitioning. Can. J. Plant Sci. 84, 79-88.

Cooper, J., Baranski, M., Stewart, G., Nobel-de Lange, M., Bàrberi, P., Fließbach, A., Peigné, J., Berner, A., Brock, C., Casagrande, M., Crowley, O., David, C., De Vliegher, A., Döring, T.F., Dupont, A., Entz, M., Grosse, M., Haase, T., Halde, C., Hammerl, V., Huiting, H., Leithold, G., Messmer, M., Schloter, M., Sukkel, W., van der Heijden, M.G.A., Willekens, K., Wittwer, R., Mäder, P., 2016. Shallow non-inversion tillage in organic farming maintains crop yields and increases soil C stocks: a meta-analysis. Agron. Sustain. Dev. 36, 22.

Fließbach, A., \& Mäder, P., 2000. Microbial biomass and size-density fractions difer between soils of organic and conventional agricultural systems. Soil Biol. Biochem, 32, 757-768.

Fließbach, A., Oberholzer, H.-R., Gunst, L., Mäder, P., 2007. Soil organic matter and biological soil quality indicators after 21 years of organic and conventional farming. Agric. Ecosyst. Environ. 118, 273-284.

Food and Agriculture Organization of the United Nations, 2013. FAO Statistical Yearbook. World food and agriculture.

Gadermaier, F., Berner, A., Fließbach, A., Friedel, J.K., Mäder, P., 2012. Impact of reduced tillage on soil organic carbon and nutrient budgets under organic farming. Renew. Agric. Food Syst. 27, 68-80.

Gattinger, A., Muller, A., Haeni, M., Skinner, C., Fliessbach, A., Buchmann, N., Mäder, P., Stolze, M., Smith, P., Scialabba, N.E.-H., Niggli, U., 2012. Enhanced top soil carbon 
527 Guo, L., Gifford, R., 2002. Soil carbon stocks and land use change: a meta analysis. Glob. 528 Chang. Biol. 8, 345-360.

529 Hernanz, J.L., Sánchez-Girón, V., Navarrete, L., 2009. Soil carbon sequestration and 530 stratification in a cereal/leguminous crop rotation with three tillage systems in semiarid 531 conditions. Agric. Ecosyst. Environ. 133, 114-122.

532 Hobbs, P.R., Sayre, K., Gupta, R., 2008. The role of conservation agriculture in sustainable 533 agriculture. Philos. Trans. R. Soc. B. 363, 543-555.

534 IUSS Working Group WRB, 2015. World reference base for soil resources 2014, update 2015. 535 International soil classification system for naming soils and creating legends for soil maps, 536 World Soil Resources Reports No. 106 FAO, Rome.

Joergensen, R. G. (1996). The fumigation-extraction method to estimate soil microbial biomass: calibration of the $k_{E C}$ value. Soil Biol. Biochem, 28, 25-31.

Joergensen, R. G., Mueller, T. (1996). The fumigation-extraction method to estimate soil microbial biomass: calibration of the $k_{E N}$ value. Soil Biol. Biochem, 28, 33-37.

Johnston, A.E., Poulton, P.R., Coleman, K., 2009. Soil Organic Matter: its importance in sustainable agriculture and carbon dioxide fluxes. Adv. Agron. 101, 1-57. E.J., Serraj, R., 2012. Conservation agriculture in the dry Mediterranean climate. F. Crop. Res. 132, 7-17.

Krauss, M., Berner, A., Burger, D., Wiemken, A., Niggli, U., Mäder, P., 2010. Reduced tillage in temperate organic farming: implications for crop management and forage production. 
549 Lal, R., 2009. Challenges and opportunities in soil organic matter research. Eur. J. Soil Sci. 60, $158-169$.

551

552

553

554

555

556

557

558

559

560

561

562

563

564

565

566

567

568

569

Lee, J., Hopmans, J.W., Rolston, D.E., Baer, S.G., Six, J., 2009. Determining soil carbon stock changes: simple bulk density corrections fail. Agric. Ecosyst. Environ. 134, 251-256.

López-Garrido, R., Madejón, E., León-Camacho, M., Girón, I., Moreno, F., Murillo, J.M., 2014. Reduced tillage as an alternative to no-tillage under Mediterranean conditions: A case study. Soil Tillage Res. 140, 40-47.

Mäder, P., Berner, A., 2012. Development of reduced tillage systems in organic farming in Europe. Renew. Agric. Food Syst. 27, 7-11.

Maltas, A., Charles, R., Jeangros, B., Sinaj, S., 2013. Effect of organic fertilizers and reducedtillage on soil properties, crop nitrogen response and crop yield: Results of a 12-year experiment in Changins, Switzerland. Soil Tillage Res. 126, 11-18.

Masilionyte, L., Maiksteniene, S., Kriauciuniene, Z., Jablonskyte-Rasce, D., Zou, L., Sarauskis, E., 2017. Effect of cover crops in smothering weeds and volunteer plants in alternative farming systems. Crop Prot. 91, 74-81.

Ministerio de Agricultura y Pesca, Alimentación y Medio Ambiente, 2009, http://www.mapama.gob.es/es/agricultura/temas/producciones-agricolas/ (accesessed 20.05.2017)

Molina-Herrera, S., Romanyà, J., 2015. Synergistic and antagonistic interactions among organic amendments of contrasted stability, nutrient availability and soil organic matter in the regulation of C mineralization. Eur. J. Soil Biol. 70, 118-125. 
Ochoa-Hueso, R., Allen, E.B., Branquinho, C., Cruz, C., Dias, T., Fenn, M.E., Manrique, E., Pérez-Corona, M.E., Sheppard, L.J., Stock, W.D., 2011. Nitrogen deposition effects on Mediterranean-type ecosystems: An ecological assessment. Environ. Pollut. 159, 22652279.

Pang, X.P., Letey, J., 2000. Organic farming: Challenge of timing nitrogen availability to crop nitrogen requirements. Soil Sci. Soc. Am. J. 64:247-253.

Peigné, J., Ball, B.C., Roger-Estrade, J., David, C., 2007. Is conservation tillage suitable for organic farming? A review. Soil Use Manag. 23, 129-144.

Peigné, J., Vian, J.-F., Cannavacciuolo, M., Lefevre, V., Gautronneau, Y., Boizard, H., 2013. Assessment of soil structure in the transition layer between topsoil and subsoil using the profil cultural method. Soil Tillage Res. 127, 13-25.

Pekrun, C., Kaul, H.-P., Claupein, W., 2003. Soil tillage for sustainable nutrient management, in: El Titi, A. (Ed.), Soil Tillage in Agroecosystems, Advances in Agroecology. CRC Press, pp. 83-106.

Plaza-Bonilla, D., Nolot, J.-M., Raffaillac, D., Justes, E., 2017. Innovative cropping systems to reduce $\mathrm{N}$ inputs and maintain wheat yields by inserting grain legumes and cover crops in southwestern France. Eur. J. Agron. 82, 31-341.

Poeplau, C., Don, A., 2015. Carbon sequestration in agricultural soils via cultivation of cover crops - A meta-analysis. Agric. Ecosyst. Environ. 200, 33-41.

R Development Core Team, 2015. R: A Language and Environment for Statistical Computing. R Foundation for Statistical Computing, Vienna, Austria. https://www.R-project.org/.

Romanyà, J., Arco, N., Solà-Morales, I., Armengot, L., Sans, F.X., 2012. Carbon and nitrogen stocks and nitrogen mineralization in organically managed soils amended with composted 
594 Romanyà, J., Rovira, P., 2011. An appraisal of soil organic C content in Mediterranean 595 agricultural soils. Soil Use Manag. 27, 321-332.

596 Sans, F.X., Berner, A., Armengot, L., Mäder, P., 2011. Tillage effects on weed communities in an organic winter wheat-sunflower-spelt cropping sequence. Weed Res. 51, 413-421.

Soil Survey Staff, 1998. Keys to soil taxonomy, Soil Conservation Service, United States Department of Agriculture.

Sparling, G.P., 1992. Ratio of microbial biomass carbon to soil organic carbon as a sensitive indicator of changes in soil organic matter. Soil Res. 30, 195-207. Charles, J. (2016). Soil microbial community and microbial residues respond positively to minimum tillage under organic farming in Southern Germany. Appl. Soil Ecol, 108, 16-24.

Vance, E.D., Brookes, P.C., Jenkinson, D.S., 1987. An extraction method for measuring soil microbial biomass C. Soil Biol. Biochem. 19, 703-707

607 Vian, J.F., Peigné, J., Chaussod, R., Roger-Estrade, J., 2009. Effects of four tillage systems on soil structure and soil microbial biomass in organic farming. Soil Use Manag. 25, 1-10.

Walley, F.L., Kyei-Boahen, S., Hnatowich, G., Stevenson, C., 2005. Nitrogen and phosphorus fertility management for desi and kabuli chickpea. Can. J. Plant Sci. 85, 73-79.

611 Ward, P.R., Flower, K.C., Cordingley, N., Weeks, C., Micin, S.F., 2012. Soil water balance 612 with cover crops and conservation agriculture in a Mediterranean climate. F. Crop. Res. $132,33-39$. 

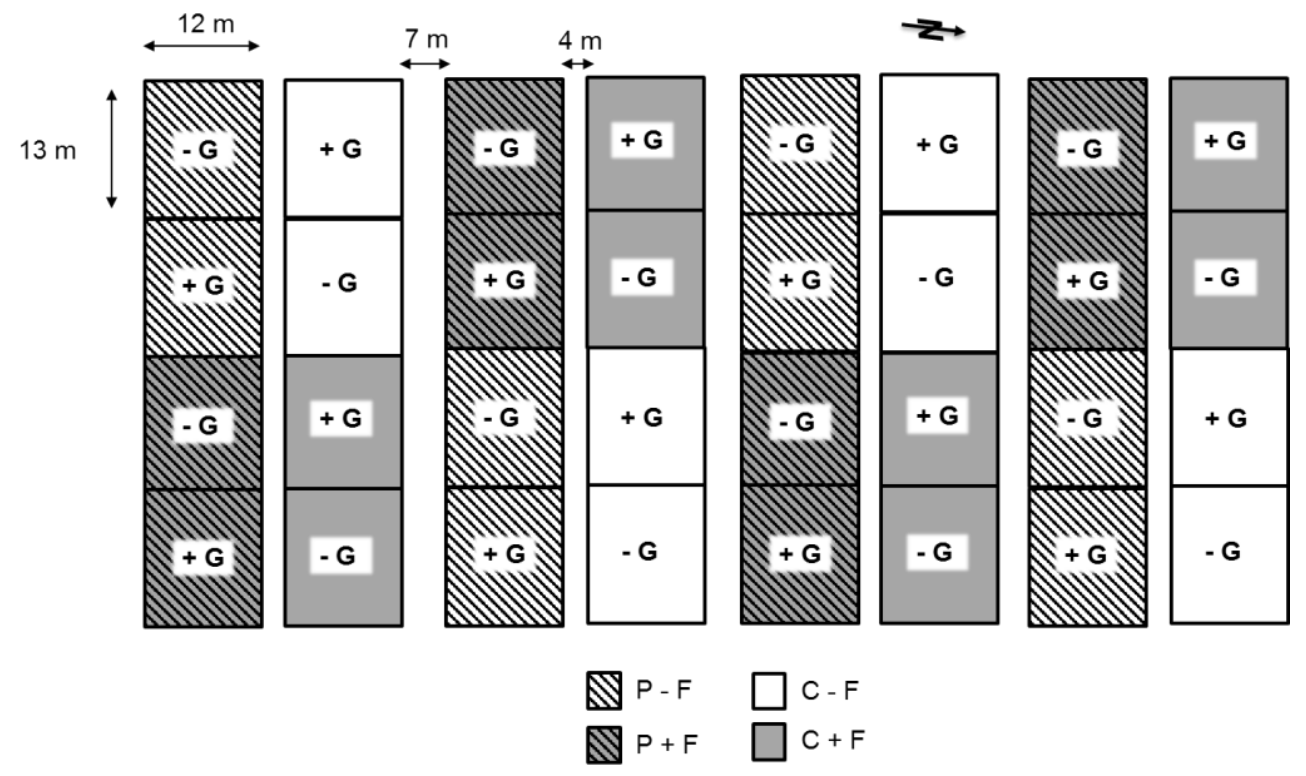

2 Figure 1. Experimental design in a strip-split-block with three factors of two levels

3 each. $\mathrm{P}$, mouldboard ploughing; $\mathrm{C}$, chisel ploughing; $+\mathrm{F}$, fertilization with farmyard

4 manure, - F, not fertilized: $+\mathrm{G}$, with green manure, $-\mathrm{G}$, no green manure. Each

5 treatment is replicated four times, totalling 32 plots. 
Table 1. Date of field operations, sowing characteristics, and fertilization inputs for each crop of the rotation. The type and brand of agricultural equipment are also indicated.

\begin{tabular}{|c|c|c|c|c|}
\hline \multirow[t]{2}{*}{ Year of rotation } & $1^{\text {st }}$ & $2^{\text {nd }}$ & $3^{\text {rd }}$ & $4^{\text {th }}$ \\
\hline & Spelt & Chickpea & Winter wheat & Lentil \\
\hline \multicolumn{5}{|l|}{ Tillage } \\
\hline \multicolumn{5}{|l|}{ Conventional tillage } \\
\hline $\begin{array}{l}\text { Mouldboard ploughing, depth } \\
25 \mathrm{~cm} \\
\text { EG } 85-240-8, \text { Kverneland }\end{array}$ & December $12^{\text {th }}, 2011$ & March $28^{\text {th }}, 2013$ & December $10^{\text {th }}, 2013$ & March $20^{\text {th }}, 2015$ \\
\hline $\begin{array}{l}\text { Rotative, depth } 5 \mathrm{~cm} \\
\text { HR3003D, Kuhn }\end{array}$ & December $14^{\text {th }}, 2011$ & April $13^{\text {th }}, 2013$ & December $16^{\text {th }}, 2013$ & March $30^{\text {th }}, 2015$ \\
\hline \multicolumn{5}{|l|}{ Reduced tillage } \\
\hline $\begin{array}{l}\text { Chisel, depth } 25 \mathrm{~cm} \\
\text { KCCC } 1187-\text { A00, Kverneland }\end{array}$ & December $14^{\text {th }}, 2011$ & March $28^{\text {th }}, 2013$ & November $12^{\text {th }}, 2013$ & March $20^{\text {th }}, 2015$ \\
\hline $\begin{array}{l}\text { Rotative, depth } 5 \mathrm{~cm} \\
\text { HR3003D, Kuhn }\end{array}$ & December $14^{\text {th }}, 2011$ & April $13^{\text {th }}, 2013$ & December $16^{\text {th }}, 2013$ & March $30^{\text {th }}, 2015$ \\
\hline \multicolumn{5}{|l|}{ Fertilization } \\
\hline $\begin{array}{l}\text { Composted cow farmyard } \\
\text { manure }\end{array}$ & December $12^{\text {th }}, 2011$ & March $28^{\text {th }}, 2013$ & November $12^{\text {th }}, 2013$ & March $19^{\text {th }}, 2015$ \\
\hline tn $\mathrm{ha}^{-1}$ & 21.5 & 22 & 38 & 22 \\
\hline $\mathrm{N}_{\mathrm{t}} \mathrm{kg} \mathrm{ha}^{-1}$ & 134.60 & 40.04 & 138.28 & 62.36 \\
\hline Weed control & No control & May 30th, 2013 & $\operatorname{March} 4^{\text {th }}, 2014$ & June $2^{\text {nd }}, 2015$ \\
\hline Machinery for weed control & & Inter-row cultivator & $\begin{array}{l}\text { Flex-tine harrow } \\
\text { Herse-6M, PICHON }\end{array}$ & Hand weeding \\
\hline $\begin{array}{l}\text { Sowing } \\
\text { Amazone D09- } 30\end{array}$ & Spelt & Chickpea & Winter wheat & Lentil \\
\hline Date of sowing & December 14th, 2011 & April 13th, 2013 & December 16th, 2013 & March 31st, 2015 \\
\hline Sowing density & $195 \mathrm{~kg} \mathrm{ha}^{-1}$ & $30 \mathrm{~kg} \mathrm{ha}^{-1}$ & $220 \mathrm{~kg} \mathrm{ha}^{-1}$ & $180 \mathrm{~kg} \mathrm{ha}^{-1}$ \\
\hline Spacing between rows & $12 \mathrm{~cm}$ & $75 \mathrm{~cm}$ & $12 \mathrm{~cm}$ & $12 \mathrm{~cm}$ \\
\hline $\begin{array}{l}\text { Harvest } \\
\text { Plot combine } \\
\text { Elite, Wintersteiger, Inc. } \\
\text { Deuthz fhar }\end{array}$ & July, $12^{\text {th }} 2012$ & July $31^{\text {st }}, 2013$ & August 12 $2^{\text {th }}, 2014$ & - \\
\hline $\begin{array}{l}\text { Disc harrowing } \\
\text { Norma RLBH 32, RAU }\end{array}$ & September $18^{\text {th }}, 2012$ & October $26^{\text {th }}, 2013$ & September $9^{\text {th }}, 2014$ & September $20^{\text {th }}, 2015$ \\
\hline Green manure & October $17^{\text {th }}, 2012$ & - & September $22^{\text {th }}, 2014$ & - \\
\hline Sowing density $\mathrm{kg} \mathrm{ha}^{-1}$ & $\begin{array}{c}45.8 \text { oat } \\
1.5 \text { mustard } \\
61 \text { bitter vetch } \\
39.7 \text { common vetch }\end{array}$ & - & $\begin{array}{c}45.8 \text { oat } \\
1.5 \text { mustard } \\
61 \text { bitter vetch } \\
39.7 \text { common vetch }\end{array}$ & - \\
\hline
\end{tabular}



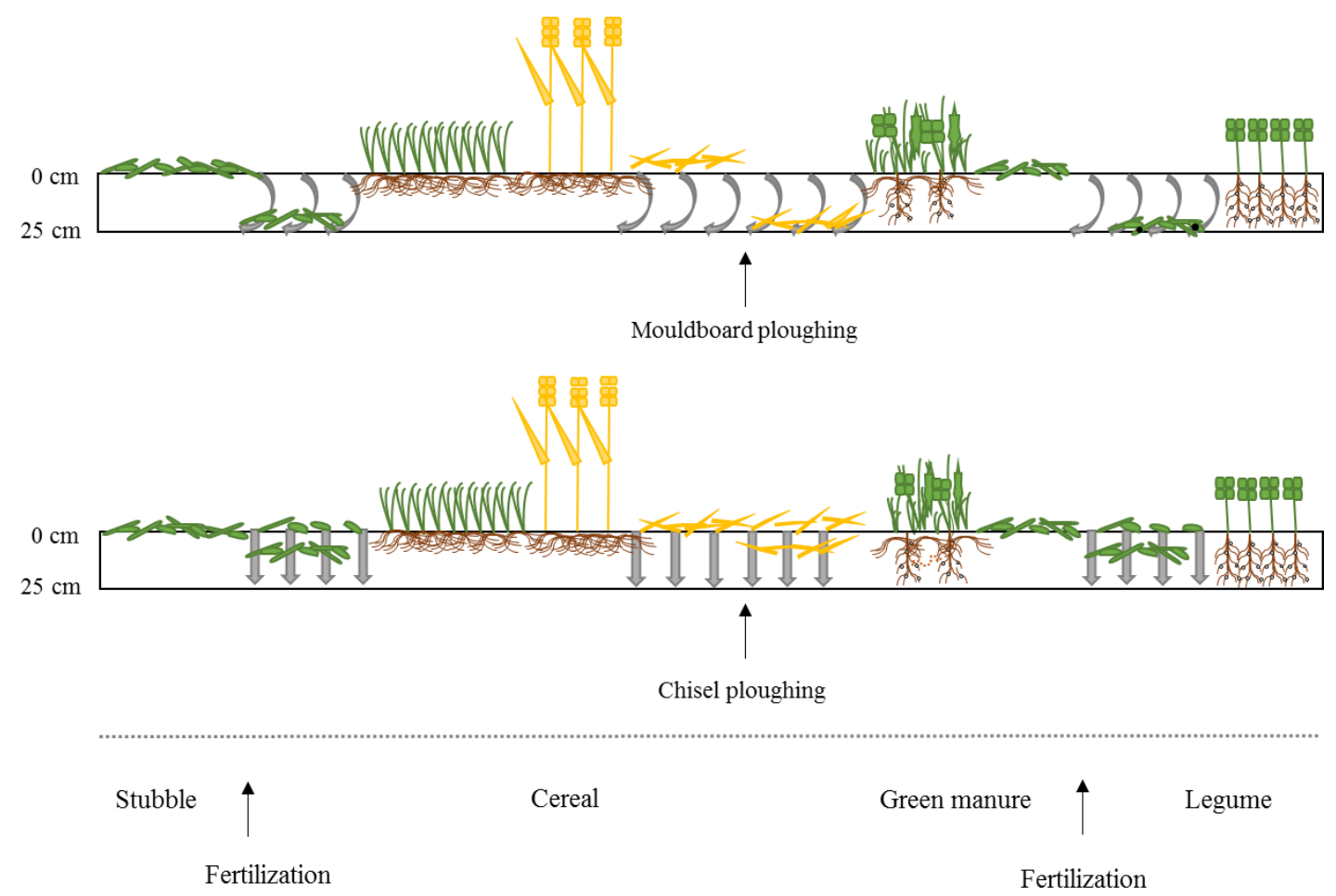

Figure 2. Cereal-legume crop rotation schemes of the experiment with two different tillage systems in two years. The first scheme (top) represents the rotation with mouldboard ploughing (inversion of soil layers) and the second scheme (bottom) represents the rotation with chisel ploughing (no soil inversion). The schemes start from the stubble incorporation of the previous crop, followed by the fertilization (in the corresponding plots) and the soil tillage for the cereal crop season. After cereal harvest and the stubble incorporation (disc harrowing), the cover crops are sown and later incorporated into the soil (in the corresponding plots), before the fertilization and tillage for the legume crop season. 
Table 2. Results of the linear mixed effects models of the effect of fertilization ( $F+$, fertilization with farmyard manure; $F$-,not fertilized), tillage system (T P: mouldboard ploughing; T C: chisel ploughing), green manure (G +, with green manure; G -, no green manure) and their interaction on the different variables measured (crop yields of spelt, chickpea and winter wheat, crop biomass of lentil, and weed biomass during each cropping season).

\begin{tabular}{|c|c|c|c|c|c|c|c|}
\hline & $\mathrm{F}(+\mathrm{vs}-)$ & $\mathrm{T}(\mathrm{P}$ vs $\mathrm{C})$ & $\mathrm{G}(+\mathrm{vs}-)$ & $\mathrm{F}(+\mathrm{vs}-) \times \mathrm{T}(\mathrm{P}$ vs $\mathrm{C})$ & $F(+$ vs -$) \times G(+$ vs -$)$ & $\mathrm{T}(\mathrm{P}$ vs $\mathrm{C}) \times \mathrm{G}(+\mathrm{vs}-)$ & $\mathrm{F} \times \mathrm{T} \times \mathrm{G}$ \\
\hline \multicolumn{8}{|l|}{ Crop yields $\left(\mathrm{kg} \mathrm{ha}^{-1}\right)$} \\
\hline Spelt & $163.06 \pm 38.25^{*}$ & $6.72 \pm 58.29^{\mathrm{NS}}$ & $23.28 \pm 22.48^{\mathrm{NS}}$ & $-26.44 \pm 22.48^{\mathrm{NS}}$ & $-2.25 \pm 22.48^{\mathrm{NS}}$ & $13.95 \pm 22.48^{\mathrm{NS}}$ & $16.92 \pm 22.48^{\mathrm{NS}}$ \\
\hline Chickpea & $-61.47 \pm 29.10^{\mathrm{NS}}$ & $-0.12 \pm 30.46^{\mathrm{NS}}$ & $5.35 \pm 15.76^{\mathrm{NS}}$ & $9.34 \pm 15.76^{\mathrm{NS}}$ & $-29.57 \pm 15.76^{\mathrm{NS}}$ & $-9.06 \pm 15.76^{\mathrm{NS}}$ & $-1.06 \pm 15.76^{\mathrm{NS}}$ \\
\hline Wheat & $484.96 \pm 121.61 *$ & $36.82 \pm 120.04^{\mathrm{NS}}$ & $28.92 \pm 68.36^{\mathrm{NS}}$ & $-45.32 \pm 68.36^{\mathrm{NS}}$ & $-8.45 \pm 68.36^{\mathrm{NS}}$ & $-4.80 \pm 68.36^{\mathrm{NS}}$ & $-1.42 \pm 68.36^{\mathrm{NS}}$ \\
\hline Lentil (biomass $\mathrm{g} \mathrm{m}^{-2}$ ) & $-7.33 \pm 5.13^{\mathrm{NS}}$ & $12.251 \pm 4.70^{*}$ & $2.47 \pm 3.87^{\mathrm{NS}}$ & $-2.16 \pm 3.87^{\mathrm{NS}}$ & $-4.18 \pm 3.87^{\mathrm{NS}}$ & $5.29 \pm 3.87^{\mathrm{NS}}$ & $-4.91 \pm 3.87^{\mathrm{NS}}$ \\
\hline \multicolumn{8}{|l|}{ Weed biomass $\left(\mathrm{g} \mathrm{m}^{-2}\right)$} \\
\hline Spelt & $-0.16 \pm 0.04 * *$ & $-0.26 \pm 0.12^{\mathrm{NS}}$ & $-0.07 \pm 0.04^{\mathrm{NS}}$ & $-0.24 \pm 0.04 * * *$ & $0.001 \pm 0.04^{\mathrm{NS}}$ & $-0.01 \pm 0.04^{\mathrm{NS}}$ & $-0.05 \pm 0.04^{\mathrm{NS}}$ \\
\hline Chickpea & $12.46 \pm 5.47^{\mathrm{NS}}$ & $-2.46 \pm 7.53^{\mathrm{NS}}$ & $1.92 \pm 3.40^{\mathrm{NS}}$ & $-2.77 \pm 3.40^{\mathrm{NS}}$ & $3.67 \pm 3.40^{\mathrm{NS}}$ & $1.09 \pm 3.40^{\mathrm{NS}}$ & $2.19 \pm 3.40^{\mathrm{NS}}$ \\
\hline Wheat & $-0.31 \pm 0.08^{*}$ & $-0.28 \pm 0.08^{*}$ & $-0.03 \pm 0.07^{\mathrm{NS}}$ & $0.11 \pm 0.07^{\mathrm{NS}}$ & $0.10 \pm 0.07^{\mathrm{NS}}$ & $0.03 \pm 0.07^{\mathrm{NS}}$ & $-0.04 \pm 0.07^{\mathrm{NS}}$ \\
\hline Lentil & $32.45 \pm 7.75^{* *}$ & $-12.79 \pm 4.25^{* *}$ & $11.55 \pm 4.25^{*}$ & $-6.88 \pm 4.25^{\mathrm{NS}}$ & $6.98 \pm 4.25^{\mathrm{NS}}$ & $-3.95 \pm 4.25^{\mathrm{NS}}$ & $0.81 \pm 4.25^{\mathrm{NS}}$ \\
\hline
\end{tabular}



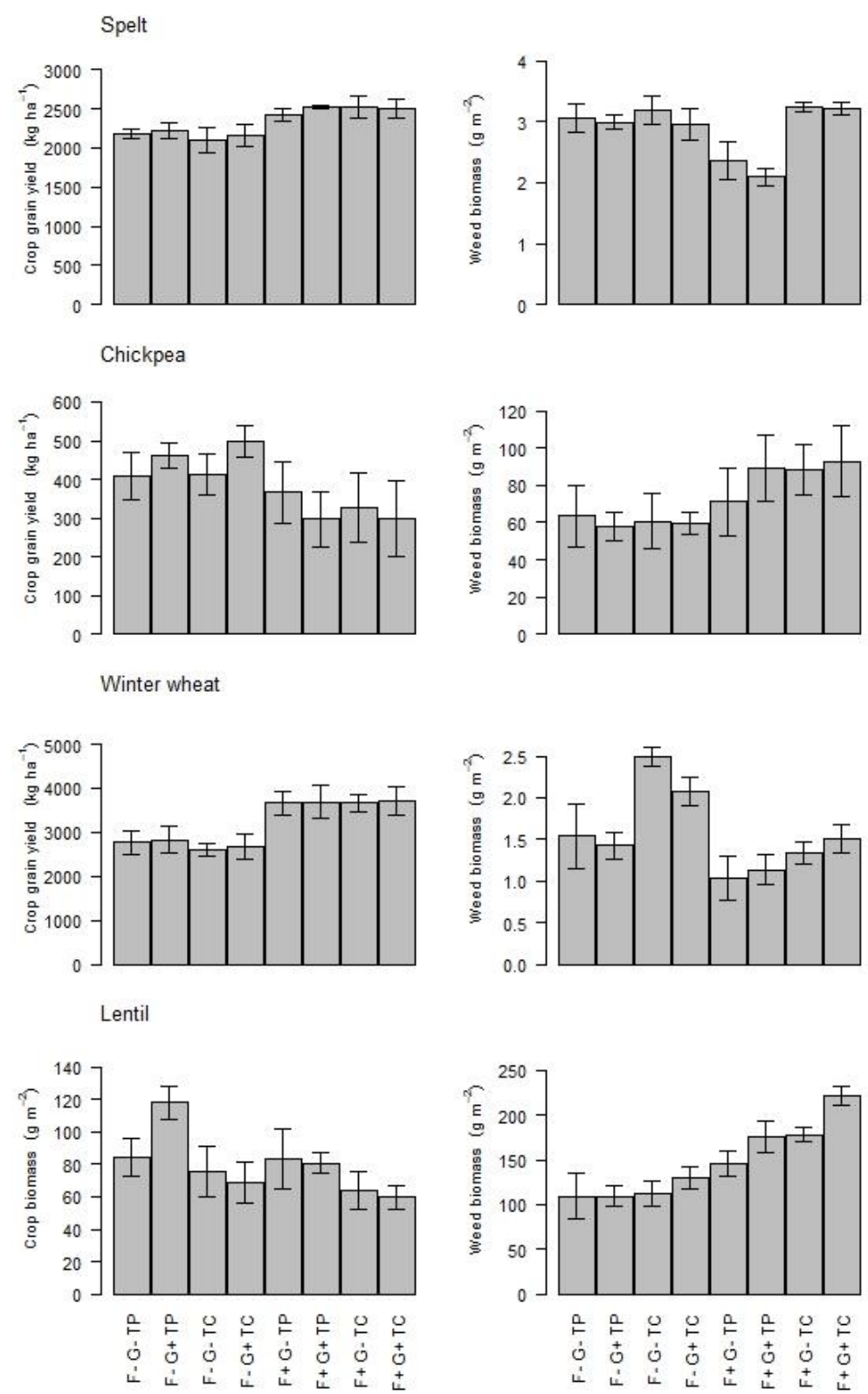

Figure 3. Mean ( \pm SE standard error of differences) crop yields of spelt, chickpea, winter wheat and crop biomass of lentil (left) and the corresponding aboveground weed biomass (right) in each treatment: fertilization ( $F$ - , not fertilized; $F+$, fertilization with farmyard manure); green manure ( $\mathrm{G}$-, no green manure; $\mathrm{G}+$ sown with green manure); tillage systems (T P, mouldboard ploughing; T C, chisel ploughing). Because lentil crop was not harvested, aboveground lentil biomass was evaluated. Note the different vertical scale for each crop. 
Table 3. Mean $( \pm \mathrm{SE})$ of $\mathrm{SOC}$ and $\mathrm{N}_{\text {tot }}$ at two soil depths $(0-10 \mathrm{~cm}$ and $10-20 \mathrm{~cm})$ in each treatment: fertilization $(\mathrm{F}+$, fertilization with farmyard manure; F -, not fertilized); tillage system (T P, mouldboard ploughing; T C, chisel ploughing); green manure (G +, sown with green manure; G -, no green manure) in the first and last year of the trial $\left(t_{i}\right.$ and $\left.t_{f}\right)$.

\begin{tabular}{|c|c|c|c|c|c|c|c|c|}
\hline & \multicolumn{2}{|c|}{$0-10 \mathrm{~cm}$} & \multicolumn{2}{|c|}{$10-20 \mathrm{~cm}$} & \multicolumn{2}{|c|}{$0-10 \mathrm{~cm}$} & \multicolumn{2}{|c|}{$10-20 \mathrm{~cm}$} \\
\hline & SOC $t_{i}$ & $\operatorname{SOC} t_{f}$ & SOC $t_{i}$ & $\operatorname{SOC} t_{f}$ & $\mathbf{N} t_{i}$ & $\mathbf{N} t_{f}$ & $\mathbf{N} t_{i}$ & $\mathbf{N} t_{f}$ \\
\hline $\mathrm{F}+$ & $1.170 \pm 0.090$ & $1.118 \pm 0.060$ & $1.110 \pm 0.090$ & $0.970 \pm 0.060$ & $0.124 \pm 0.005$ & $0.163 \pm 0.006$ & $0.113 \pm 0.006$ & $0.148 \pm 0.006$ \\
\hline F - & $1.150 \pm 0.130$ & $0.827 \pm 0.060$ & $1.090 \pm 0.120$ & $0.800 \pm 0.040$ & $0.119 \pm 0.007$ & $0.127 \pm 0.005$ & $0.112 \pm 0.005$ & $0.123 \pm 0.005$ \\
\hline $\mathrm{TP}$ & $1.140 \pm 0.100$ & $0.904 \pm 0.036$ & $1.090 \pm 0.100$ & $0.900 \pm 0.030$ & $0.120 \pm 0.005$ & $0.139 \pm 0.003$ & $0.110 \pm 0.005$ & $0.137 \pm 0.005$ \\
\hline $\mathrm{T} \mathrm{C}$ & $1.180 \pm 0.120$ & $1.042 \pm 0.080$ & $1.110 \pm 0.120$ & $0.860 \pm 0.070$ & $0.121 \pm 0.006$ & $0.152 \pm 0.008$ & $0.114 \pm 0.006$ & $0.134 \pm 0.006$ \\
\hline $\mathrm{G}+$ & $1.180 \pm 0.120$ & $0.97 \pm 0.060$ & $1.120 \pm 0.120$ & $0.880 \pm 0.050$ & $0.121 \pm 0.006$ & $0.144 \pm 0.005$ & $0.114 \pm 0.006$ & $0.136 \pm 0.006$ \\
\hline G - & $1.140 \pm 0.100$ & $0.975 \pm 0.050$ & $1.080 \pm 0.100$ & $0.890 \pm 0.040$ & $0.122 \pm 0.006$ & $0.146 \pm 0.006$ & $0.110 \pm 0.005$ & $0.135 \pm 0.005$ \\
\hline
\end{tabular}


Table 4. Results of the linear mixed effects models of the effect of the different experimental factors, plus depth and year and their interactions on the changes in soil organic carbon, in total nitrogen and in the ratio among these ( $\triangle \mathrm{SOC}, \Delta \mathrm{N}$ and $\Delta \mathrm{C}: \mathrm{N}) . \mathrm{F}+$, fertilization with farmyard manure; F -, not fertilized; T P, mouldboard ploughing; T C, chisel ploughing; G +, sown with green manure; G -, no green manure.

\begin{tabular}{|c|c|c|c|}
\hline & $\triangle \mathrm{SOC}$ & $\Delta \mathbf{N}$ & $\Delta \mathbf{C}: \mathbf{N}$ \\
\hline $\mathrm{F}(+\mathrm{vs}-)$ & $0.137 \pm 0.075^{\mathrm{NS}}$ & $0.015 \pm 0.002 * * *$ & $0.264 \pm 0.675^{\mathrm{NS}}$ \\
\hline $\mathrm{T}(\mathrm{P}$ vs $\mathrm{C})$ & $-0.049 \pm 0.060^{\mathrm{NS}}$ & $-0.008 \pm 0.001 * * *$ & $0.085 \pm 0.579^{\mathrm{NS}}$ \\
\hline $\mathrm{G}(+\mathrm{vs}-)$ & $-0.021 \pm 0.020^{\mathrm{NS}}$ & $-0.001 \pm 0.001^{\mathrm{NS}}$ & $-0.169 \pm 0.188^{\mathrm{NS}}$ \\
\hline $\mathrm{F}(+\mathrm{vs}-) \times \mathrm{T}(\mathrm{P}$ vs $\mathrm{C})$ & $0.009 \pm 0.020^{\mathrm{NS}}$ & $-0.006 \pm 0.001 * *$ & $0.452 \pm 0.188 *$ \\
\hline $\mathrm{F}(+\mathrm{vs}-) \times \mathrm{G}(+\mathrm{vs}-)$ & $-0.007 \pm 0.020^{\mathrm{NS}}$ & $-0.002 \pm 0.001^{\mathrm{NS}}$ & $0.082 \pm 0.188^{\mathrm{NS}}$ \\
\hline $\mathrm{T}(\mathrm{P}$ vs $\mathrm{C}) \times \mathrm{G}(+\mathrm{vs}-)$ & $-0.022 \pm 0.020^{\mathrm{NS}}$ & $-0.002 \pm 0.001^{\mathrm{NS}}$ & $0.007 \pm 0.189^{\mathrm{NS}}$ \\
\hline Depth $(10-20$ vs $0-10 \mathrm{~cm})$ & $-0.025 \pm 0.029^{\mathrm{NS}}$ & $-0.001 \pm 0.002^{\mathrm{NS}}$ & $-0.461 \pm 0.267^{\mathrm{NS}}$ \\
\hline $\mathrm{F}(+\mathrm{vs}-) \times$ depth $(10-20$ vs $0-10 \mathrm{~cm})$ & $-0.060 \pm 0.029 *$ & $-0.003 \pm 0.002^{\mathrm{NS}}$ & $-0.297 \pm 0.267^{\mathrm{NS}}$ \\
\hline $\mathrm{T}(\mathrm{P}$ vs $\mathrm{C}) \times$ depth $(10-20$ vs $0-10 \mathrm{~cm})$ & $0.084 \pm 0.029 * *$ & $0.012 \pm 0.002 * * *$ & $-0.021 \pm 0.267^{\mathrm{NS}}$ \\
\hline $\mathrm{G}(+\mathrm{vs}-) \times$ depth $(10-20$ vs $0-10 \mathrm{~cm})$ & $-0.002 \pm 0.029^{\mathrm{NS}}$ & $-0.002 \pm 0.002^{\mathrm{NS}}$ & $0.180 \pm 0.267^{\mathrm{NS}}$ \\
\hline $\mathrm{F}(+\mathrm{vs}-) \times \mathrm{T}(\mathrm{P}$ vs $\mathrm{C}) \times \operatorname{depth}(10-20$ vs $0-10 \mathrm{~cm})$ & $0.0578 \pm 0.29^{\mathrm{NS}}$ & $0.006 \pm 0.002 *$ & $0.190 \pm 0.267^{\mathrm{NS}}$ \\
\hline
\end{tabular}

The values are estimated differences in marginal means, standard errors and their significance levels, which are indicated according to the following codes: $* * * \mathrm{p}<0.001, * * \mathrm{p}<0.01, * \mathrm{p}<0.05$, NS not significant. 


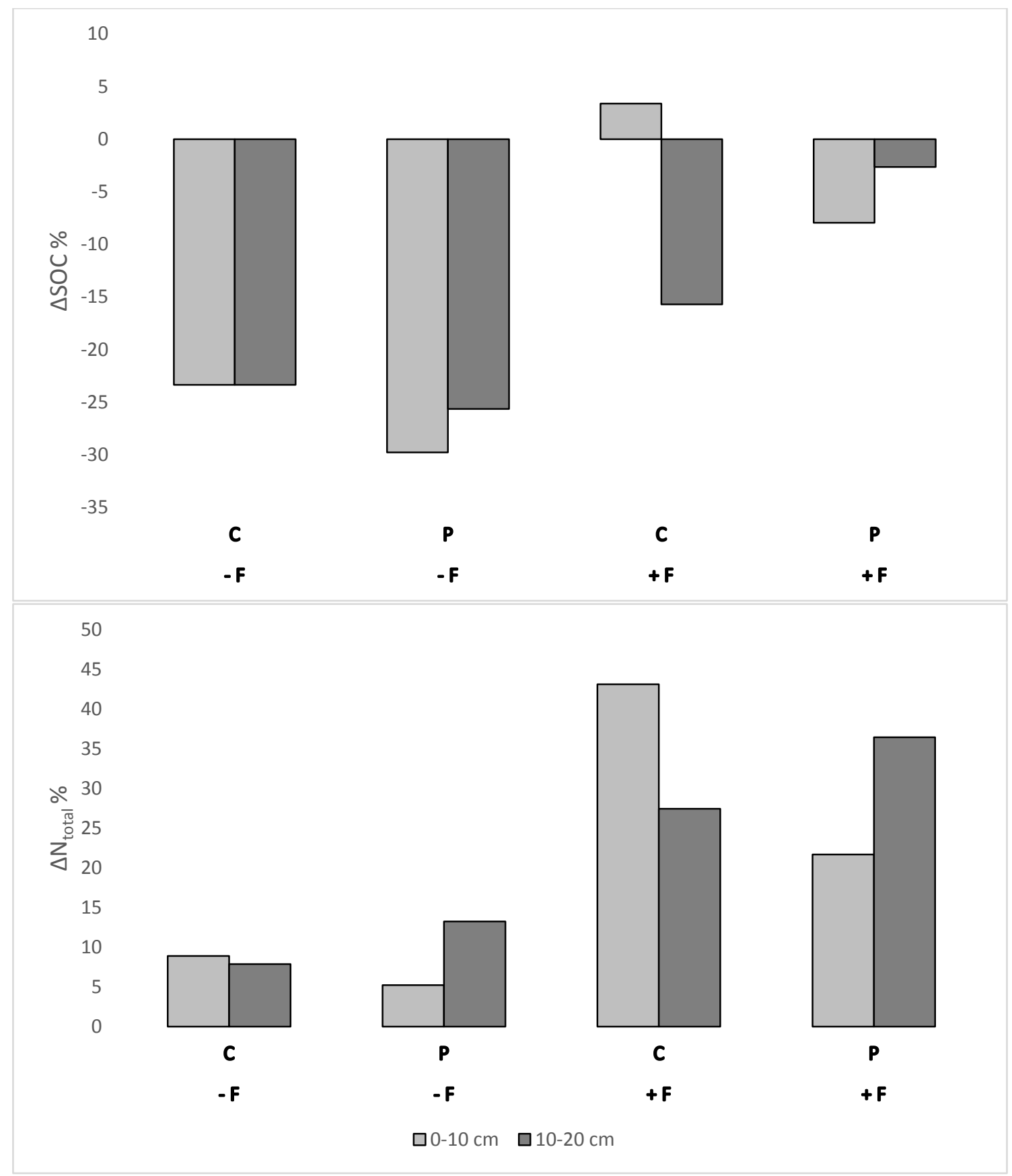

Figure 4. Changes in SOC and N contents, at two soil depths (0 to $10 \mathrm{~cm}$ and 10 to 20 $\mathrm{cm}$ ), in plots under different treatments over the 4-year rotation of the experiment. Fertilization ( $\mathrm{F}$-, not fertilized; $\mathrm{F}+$, fertilization with farmyard manure); tillage system ( $\mathrm{P}$, mouldboard ploughing; $\mathrm{C}$ chisel ploughing). $\Delta \mathrm{SOC}$ and $\Delta \mathrm{N}_{\text {tot }}$ represent the differences between the $t_{f}$ and the $t_{i}$. 
Table 5. Results of the linear mixed effects models of the effect of the different factors: fertilization (F + fertilization with farmyard, $\mathrm{F}$ - not fertilized; manure); tillage system (T P, mouldboard ploughing; T C, chisel ploughing); green manure (G -, no green manure; G +, sown with green manure); depth ( $1,0-10 \mathrm{~cm} ; 2,10-20 \mathrm{~cm})$; and the interaction between them on soil bulk density and carbon stocks after the four years of trial $\left(t_{f}\right)$.

\begin{tabular}{|c|c|c|}
\hline & Bulk density $\left(t_{f}\right)$ & Carbon stocks $\left(t_{f}\right)$ \\
\hline $\mathrm{F}(+\mathrm{vs}-)$ & $-0.0038 \pm 0.017^{\mathrm{NS}}$ & $1064.77 \pm 295.35^{*}$ \\
\hline $\mathrm{T}(\mathrm{P}$ vs $\mathrm{C})$ & $-0.007 \pm 0.015^{\mathrm{NS}}$ & $415.15 \pm 334.56^{\mathrm{NS}}$ \\
\hline $\mathrm{G}(+\mathrm{vs}-)$ & $-0.003 \pm 0.015^{\mathrm{NS}}$ & $-149.21 \pm 203.76^{\mathrm{NS}}$ \\
\hline $\mathrm{F}(+\mathrm{vs}-) \times \mathrm{T}(\mathrm{P}$ vs $\mathrm{C})$ & $0.012 \pm 0.015^{\mathrm{NS}}$ & $18.22 \pm 203.76^{\mathrm{NS}}$ \\
\hline $\mathrm{F}(+\mathrm{vs}-) \times \mathrm{G}(+\mathrm{vs}-)$ & $0.008 \pm 0.015^{\mathrm{NS}}$ & $130.66 \pm 203.76^{\mathrm{NS}}$ \\
\hline $\mathrm{T}(\mathrm{P}$ vs $\mathrm{C}) \times \mathrm{G}(+\mathrm{vs}-)$ & $0.003 \pm 0.015^{\mathrm{NS}}$ & $597.26 \pm 203.76^{* *}$ \\
\hline Depth (10-20 vs 0-10 cm) & $0.259 \pm 0.022 * * *$ & $1234.81 \pm 269.12^{* * *}$ \\
\hline $\mathrm{F}(+\mathrm{vs}-) \times$ depth $(10-20$ vs $0-10 \mathrm{~cm})$ & $-0.017 \pm 0.022^{\mathrm{NS}}$ & $716.31 \pm 269.12^{*}$ \\
\hline $\mathrm{T}(\mathrm{P}$ vs $\mathrm{C}) \times$ depth $(10-20$ vs $0-10 \mathrm{~cm})$ & $0.021 \pm 0.022^{\mathrm{NS}}$ & $-1287.24 \pm 269.12 * * *$ \\
\hline $\mathrm{G}(+\mathrm{vs}-) \times \operatorname{depth}(10-20$ vs $0-10 \mathrm{~cm})$ & $-0.010 \pm 0.022^{\mathrm{NS}}$ & $96.99 \pm 269.12^{\mathrm{NS}}$ \\
\hline
\end{tabular}

The values are estimated differences in marginal means, standard errors and their significance levels, which are indicated according to the following codes: $* * * \mathrm{p}<0.001, * * \mathrm{p}<0.01, * \mathrm{p}<0.05, \mathrm{NS}$ not significant. 
Table 6. Mean $( \pm \mathrm{SE})$ of soil microbial biomass $\left(\mathrm{C}_{\text {mic }}\right.$ and $\left.\mathrm{N}_{\text {mic }}\right)$ and the ratio $\left(\mathrm{C}_{\text {mid }} / \mathrm{SOC}\right)$ in the last year of the trial $\left(t_{f}\right)$ at two soil depths $(0-10$ $\mathrm{cm}$ and $10-20 \mathrm{~cm})$ in each treatment: fertilization $(\mathrm{F}+$, fertilization with farmyard manure; $\mathrm{F}-$, not fertilized); tillage system (T P, mouldboard ploughing; $\mathrm{T}$ C, chisel ploughing); green manure ( $\mathrm{G}+$, sown with green manure; $\mathrm{G}$ - no green manure).

\begin{tabular}{|c|c|c|c|c|c|c|}
\hline System & $\mathrm{C}_{\mathrm{mic}}(\mu$ & $\left.\mathrm{g}^{-1}\right)\left(t_{f}\right)$ & $\mathbf{N}_{\text {mic }}(\mu$ & $\left.\mathrm{g}^{-1}\right)\left(t_{f}\right)$ & $\mathrm{C}_{\mathrm{mic}} / \mathrm{SO}$ & $C(\%)\left(t_{f}\right)$ \\
\hline Depth & $0-10 \mathrm{~cm}$ & $10-20 \mathrm{~cm}$ & $0-10 \mathrm{~cm}$ & $10-20 \mathrm{~cm}$ & $0-10 \mathrm{~cm}$ & $10-20 \mathrm{~cm}$ \\
\hline $\mathrm{F}+$ & $297.13 \pm 15.66$ & $250.48 \pm 11.66$ & $\overline{31.81 \pm 7.00}$ & $\overline{25.27 \pm 4.13}$ & $2.64 \pm 0.31$ & $2.57 \pm 0.36$ \\
\hline F - & $234.73 \pm 13.59$ & $210.48 \pm 12.65$ & $19.70 \pm 3.51$ & $24.37 \pm 4.75$ & $2.88 \pm 0.41$ & $2.60 \pm 0.24$ \\
\hline T P & $243.34 \pm 12.93$ & $234.41 \pm 11.00$ & $26.37 \pm 4.62$ & $27.60 \pm 4.86$ & $2.72 \pm 0.31$ & $2.61 \pm 0.26$ \\
\hline $\mathrm{TC}$ & $288.53 \pm 16.31$ & $226.56 \pm 13.31$ & $25.14 \pm 5.89$ & $22.04 \pm 4.02$ & $2.80 \pm 0.41$ & $2.56 \pm 0.33$ \\
\hline $\mathrm{G}+$ & $269.04 \pm 14.50$ & $231.69 \pm 11.85$ & $26.33 \pm 5.85$ & $25.44 \pm 5.66$ & $2.80 \pm 0.39$ & $2.61 \pm 0.32$ \\
\hline G - & $262.82 \pm 14.74$ & $229.27 \pm 12.45$ & $25.18 \pm 4.65$ & $24.19 \pm 3.22$ & $2.72 \pm 0.34$ & $2.55 \pm 0.28$ \\
\hline
\end{tabular}


Table 7. Results of the linear mixed effects models of the effect of the different factors: fertilization ( $\mathrm{F}+$, fertilization with farmyard manure; $\mathrm{F}$-, not fertilized); tillage system (T P, mouldboard ploughing; T C, chisel ploughing); green manure ( $\mathrm{G}+$, sown with green manure; $\mathrm{G}$ - no green manure; depth $(0-10 \mathrm{~cm}$ and $10-20 \mathrm{~cm})$; and the interaction between them on $\mathrm{C}_{\text {mic }}, \mathrm{N}_{\text {mic }}$ and $\mathrm{C}_{\text {mid }} / \mathrm{SOC}$ in the last year of the trial $\left(t_{f}\right)$.

\begin{tabular}{lccc}
\hline \multicolumn{1}{c}{ System } & $\mathbf{C}_{\text {mic }}\left(\boldsymbol{t}_{f}\right)$ & $\mathbf{N}_{\text {mic }}\left(\boldsymbol{t}_{f}\right)$ & $\mathbf{C}_{\mathbf{m i c}} / \mathbf{S O C}\left(\boldsymbol{t}_{f}\right)$ \\
\hline F (+ vs -) & $30.77 \pm 3.56^{* * *}$ & $5.91 \pm 2.71^{*}$ & $-0.10 \pm 0.21^{\mathrm{NS}}$ \\
T (P vs C) & $-21.66 \pm 14.93^{\mathrm{NS}}$ & $0.74 \pm 2.25^{\mathrm{NS}}$ & $-0.07 \pm 0.05^{\mathrm{NS}}$ \\
G (+ vs -) & $3.02 \pm 4.02^{\mathrm{NS}}$ & $0.58 \pm 2.25^{\mathrm{NS}}$ & $0.03 \pm 0.03^{\mathrm{NS}}$ \\
Depth (10-20 vs 0-10 cm) & $-35.69 \pm 3.77^{* * *}$ & $-1.06 \pm 2.05^{\mathrm{NS}}$ & $-0.15 \pm 0.07^{*}$ \\
F (+ vs -) $\times$ depth (10-20 vs 0-10 cm) & $-11.57 \pm 3.78^{* *}$ & $-5.04 \pm 2.05^{*}$ & $0.11 \pm 0.07^{\mathrm{NS}}$ \\
T (P vs C) $\times$ depth (10-20 vs 0-10 cm) & $26.38 \pm 3.78^{* * *}$ & $1.40 \pm 2.04^{\mathrm{NS}}$ & $0.07 \pm 0.07^{\mathrm{NS}}$ \\
F (+ vs -) $\times$ T (P vs C) & $-3.13 \pm 3.42^{\mathrm{NS}}$ & $-1.41 \pm 2.25^{\mathrm{NS}}$ & $0.11 \pm 0.05^{*}$ \\
F (+ vs -) $\times$ T (P vs C) $\times$ depth $(10-20$ vs 0-10 cm) & $-6.04 \pm 6.23^{\mathrm{NS}}$ & $-0.25 \pm 2.05^{\mathrm{NS}}$ & $-0.27 \pm 0.07^{* * *}$ \\
\hline
\end{tabular}

Significance levels are indicated according to the following codes: $* * * \mathrm{p}<0.001, * * \mathrm{p}<0.01, * \mathrm{p}<0.05$, ${ }^{\mathrm{NS}}$ not significant. Interactions with the green manure were not significant. 

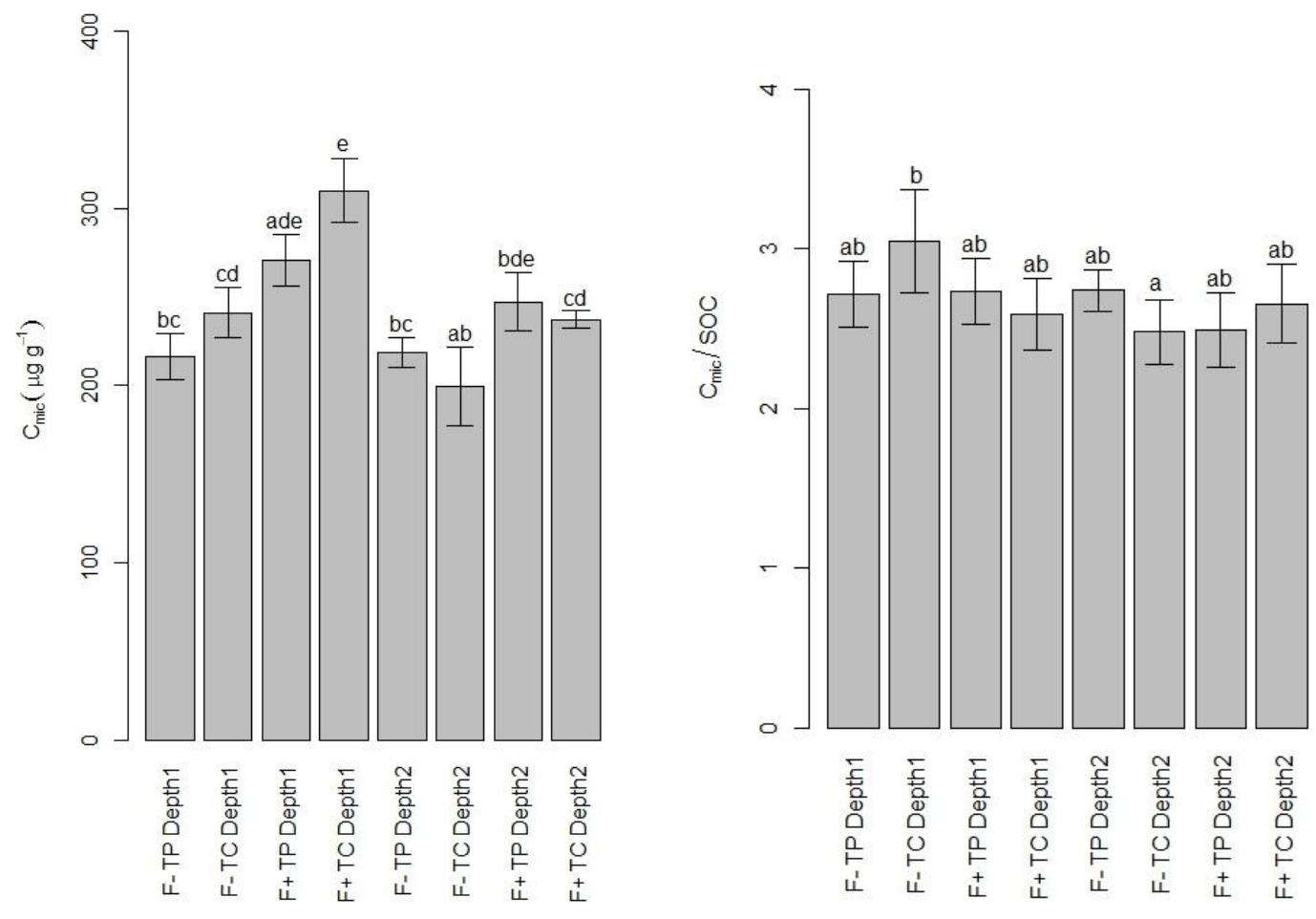

Figure 5. Soil microbial biomass $\mathrm{C}$ (left) and $\mathrm{C}_{\text {mic }} / \mathrm{SOC}$ ratio (right, in percentage) after four years of the trial $\left(\mathrm{t}_{\mathrm{f}}\right)$ in the different treatments: fertilization $(\mathrm{F}+$ fertilization with farmyard manure, $\mathrm{F}$ - not fertilized); tillage system (T P mouldboard ploughing, T C chisel ploughing); green manure $(\mathrm{G}+$ sown with green manure, $\mathrm{G}$ - no green manure); depth $(1: 0-10 \mathrm{~cm}, 2: 10-$ $20 \mathrm{~cm}$ ). Bars with no letters in common are significantly different (Tukey HSD test, $\mathrm{p}<0.05$ ). 